\title{
Aluviální zlato v oblasti Dlouhá Ves - Řepová (zábřežské krystalinikum)
}

\author{
Alluvial gold in the area Dlouhá Ves - Řepová (Zábřeh Crystalline Complex)
}

\author{
ZdeněK Dolníček ${ }^{1) *}$, Miroslav Nepejchal ${ }^{2)}$ a Jana Ulmanová ${ }^{1)}$ \\ ${ }^{1)}$ Mineralogicko-petrologické oddělení, Národní muzeum, Cirkusová 1740, 19300 Praha 9; \\ *e-mail: zdenek.dolnicek@nm.cz \\ 2) Žižkova 8, 78701 Šumperk
}

Dolniček Z, Nepejchal M, Ulmanová J (2020) Aluviální zlato v oblasti Dlouhá Ves - Řepová (zábřežské krystalinikum). Bull Mineral Petrolog 28(1): 9-22 ISSN 2570-7337

\begin{abstract}
A detailed panning prospection of the Řepovský potok, Míroveček and Ospitský potok creeks (northern part of the Zábřeh Upland) proved that trace amount of alluvial gold occurs in the whole studied area. The collected gold sheets are 0.2 to $3 \mathrm{~mm}$ in size and mostly have shapes only weakly modified by transport in the stream. Although the chemical composition varies widely between Au-rich silver and pure gold (28.1 - 99.8 at. \% Au), individual sheets are typically (few exceptions exist) compositionally homogeneous. Less than half of them has the narrow high-fineness rim, which was formed by leaching of silver in supergene conditions. In lower reach of the Repovský potok creek there were also found gold sheets containing elevated mercury $(0.1-5.1$ at. \%), which most probably originated from neighbouring vein-type Ag-Zn-Pb deposit Repová. In contrast, the source of Hg-free gold sheets was not unambiguously established. The first possibility includes small vein-type mineralizations similar to the Repová ore deposit and containing trace amount of gold (an occurrence of this type was newly recognized in the vicinity of Dlouhá Ves village). Second, one cannot exclude the trace occurrence of gold sheets directly in underlying metasiltstones or acid metavolcanic rocks of the Zábřeh Crystalline Complex [with respect to repeatedly observed intergrowths of gold with polymineral aggregates of phyllosilicates (muscovite, chlorite, biotite, clay minerals), feldspars (K-feldspar, albite, K-Na feldspar) and minor quartz in the alluvial gold sheets]. The particles of metallic $\mathrm{Cu}-\mathrm{Zn}-\mathrm{Sn}$ alloys with admixture of $\mathrm{Ni}, \mathrm{Sb}$ and $\mathrm{In}$, panned from the Řepovský potok creek, could contain metals originated from smelting of base-metals ores from the deposit Řepová, which comprise the same minor elements.
\end{abstract}

Key words: gold, silver, mercury, electrum, base-metals vein mineralization, Řepová, Zábřeh Crystalline Complex

Obdrženo 21. 1. 2020; prijiato 18. 3. 2020

\section{Úvod}

Sporé historické zprávy uvádějí, že v severní části Zábřežské vrchoviny probíhaly na vodních tocích $v$ oblasti severozápadně od Mohelnice pokusy s rýžováním zlata. Konkrétně jsou v dostupné literatuře zmiňovány toky Řepovského potoka, Hynčinského potoka a Ospitského potoka. Ve zprávě z roku 1594 se hovoří o haviríi, který u Hynčiny získával zlato na „wasswerke“, tedy propíráním říčních náplavů (Štěpán 2004). Nakolik ale tato činnost byla úspěšná, není známo. Sporadické drobné zlatinky byly vyrýžovány $z$ náplavů všech výše zmíněných toků během různých šlichovacích akcí ve 2 . polovině 20 . století (Albrechtová, Zielinová 1984; Rezek 1984; Malec et al. 1990; Abraham et al. 1995; Morávek 2015; Petržela 2016).

O potenciálních primárních zdrojích zlata není v dané oblasti známo téměř nic. Žádné specializované zlatonosné mineralizace dosud nebyly z oblasti zábřežského krystalinika popsány. Jediný drobný výskyt zlata je znám z žilného baryt-polymetalického rudního ložiska, situovaného již v oblasti mírovského paleozoika asi $0.5 \mathrm{~km}$ jižně od Řepové. Rezek (1984) vyrýžoval ze svahovin na úbočí kóty Kamenná nad Řepovským potokem a pod opuště- ným žilným ložiskem tři světle žluté zlatinky s vysokým obsahem stříbra (X0 \%), u nichž autor předpokládal, že pocházejí z výše zmíněného rudního ložiska. Jeho hypotézu nově potvrdili Dolníček et al. (2019) nálezem čtyř zlatinek $v$ baryt-sulfidické rudnině řepovského ložiska. Tento nález vzbudil zájem autorů předložené práce i o problematiku aluviálního zlata. Již první orientační šlichovací zkouška, provedená autory této práce na Řepovském potoce pod řepovským rudním ložiskem, však ukázala, že v povodí tohoto toku musí existovat více zdrojủ aluviálního zlata: většina vyrýžovaných zlatinek měla v porovnání se zlatem z polymetalického ložiska Řepová výrazně vyšší ryzost a často i dobře vyvinuté okrajové lemy ryzejšího zlata. Následný výzkum se tedy soustředil na horní tok Řepovského potoka a posléze i na dva další malé vodní toky v okolí. Výsledky, získané během všech těchto prací, sumarizuje předložený spis.

\section{Geologická pozice}

Zájmová oblast této práce zahrnuje toky Řepovského potoka, Mírovečku a horní tok Ospitského potoka (obr. 1). Geologické podloží této oblasti je budováno třemi geologickými jednotkami - zábřežským krystalinikem, 
mírovským paleozoikem a kvartérním pokryvem (obr. 1). Nejstarší horniny náleží zábřežskému krystaliniku, jež na povrch vystupuje v téměř celé zájmové oblasti s výjimkou dolního toku Řepovského potoka (obr. 1). Jde o varisky metamorfovanou horninovou sekvenci, jejíž protolit má spodnopaleozoické a proterozoické stárí (Koverdynský, Konzalová 1986; Morávek 1995). Intenzita metamorfózy roste směrem k SZ od facie zelených břidlic po facii amfibolitovou (Morávek 1995). Hlavním litotypem jsou v zájmové oblasti metaprachovce, v nichž se vyskytují tělesa amfibolitů a serpentinitů (obr. 1). Metaprachovce (,fylity“) jsou texturně i minerálním složením velmi proměnlivé horniny, s výskytem typů zřetelně páskovaných až po typy s nezřetelně vyvinutou foliací. Místy obsahují vložky grafitických břidlic, kvarcitů, mramorů, zelených břidlic a kyselých metavulkanitů (Morávek 1995). Horniny zábřežského krystalinika tvořily podklad, na nějž se později ukládaly i sedimenty mírovského paleozoika a kvartéru.

Mírovské paleozoikum (ve starší literatuře označované i jako mírovský „kulm“) v zájmové oblasti vystupuje pouze na dolním toku Řepovského potoka (obr. 1). Je tvořeno slabě metamorfovanými sedimenty mohelnického souvrství, reprezentovaných zejména břidlicemi, slepenci a drobami, podružně i vápenci. Ve spodní části vrstevního sledu (trnávecké břidlice) bylo paleontologicky doloženo devonské (givet) stáŕí (Zapletal 1994; Otava et al. 1994). Sedimentární sekvence spočívá diskordantně na metamorfitech zábřežského krystalinika. Významným litotypem jsou petromiktní mírovské slepence, jejichž valounový materiál (křemen, sericitické a sericiticko-chloritické kvarcity, fylity, svory, ruly, kontaktní rohovce, diabasy, amfibolity) pocházel zejména z podložního zábřežského krystalinika (Štelcl, Brothánek 1961).

Údolí potoků a říček jsou vyplněna kvartérními fluviálními sedimenty, ve vyšších částech svahů jsou hojná i hlinito-kamenitá deluvia, místy i eolické sedimenty (spraše) a deluvioeolické sedimenty (obr. 1).

\section{Metodika}

V první fázi provedl druhý z autorů šlichovou prospekci horních toků Řepovského potoka, Mírovečku a Ospitského potoka (obr. 2). Vzorky byly odebírány jak z potočních sedimentů aktivního koryta, tak z deluvií na svazích. Vzhledem ke skutečnosti, že zlatonosné sedimenty bývají v dané oblasti překryty vrstvou sterilních uloženin, byl materiál pro šlichování odebírán z ručně kopaných sond z hloubky několika desítek centimetrů. Odebraný materiál byl hned na místě vyrýžován na prospektorské pánvi (bez předchozího sítování) a prrítomnost zlata byla v získaném šlichu posléze ověřena prohlídkou pod binokulární lupou. Dále byly prověřovány i odebrané skalní horniny, případně nalezená hydrotermální mineralizace. Tyto materiály byly šlichovány po předchozím manuálním rozdrcení v ocelovém hmoždírii. Celkem bylo takto zpracováno a vyhodnoceno několik desítek šlichových vzorků.

Fotografie zlatinek $v$ napadajícím světle byly pořízeny pomocí mikroskopu Nikon SMZ 25 s digitální kamerou Nikon DS-Ri2 a funkce skládání obrazu za použití programu NIS Elements AR verze 4.20. Reprezentativní výběr nalezených zlatinek a dalších rudních minerálů, stejně jako vizuálně neidentifikovaná zrna, byly ze šlichů ručně vyseparovány pod binokulární lupou, zality do epoxidové tablety a naleštěny pomocí diamantových suspenzí. Další nábrusy byly zhotoveny z nalezených vzorků hydrotermální mineralizace. Dokumentace zhotovených preparátů v odraženém světle byla provedena na odrazovém polarizačním mikroskopu Nikon Eclipse ME 600 v Národním muzeu v Praze.

Následně byly nábrusy vakuově napařeny vrstvičkou uhlíku o tloušt'ce $30 \mathrm{~nm}$ a studovány pomocí elektronové mikrosondy Cameca SX-100 v laboratoři Mineralogickopetrologického oddělení Národního muzea v Praze. Na přistroji byly pořízeny fotografie ve zpětně odražených elektronech (BSE), provedena identifikace přítomných fází pomocí energiově-disperzních (EDS) spekter a mě-

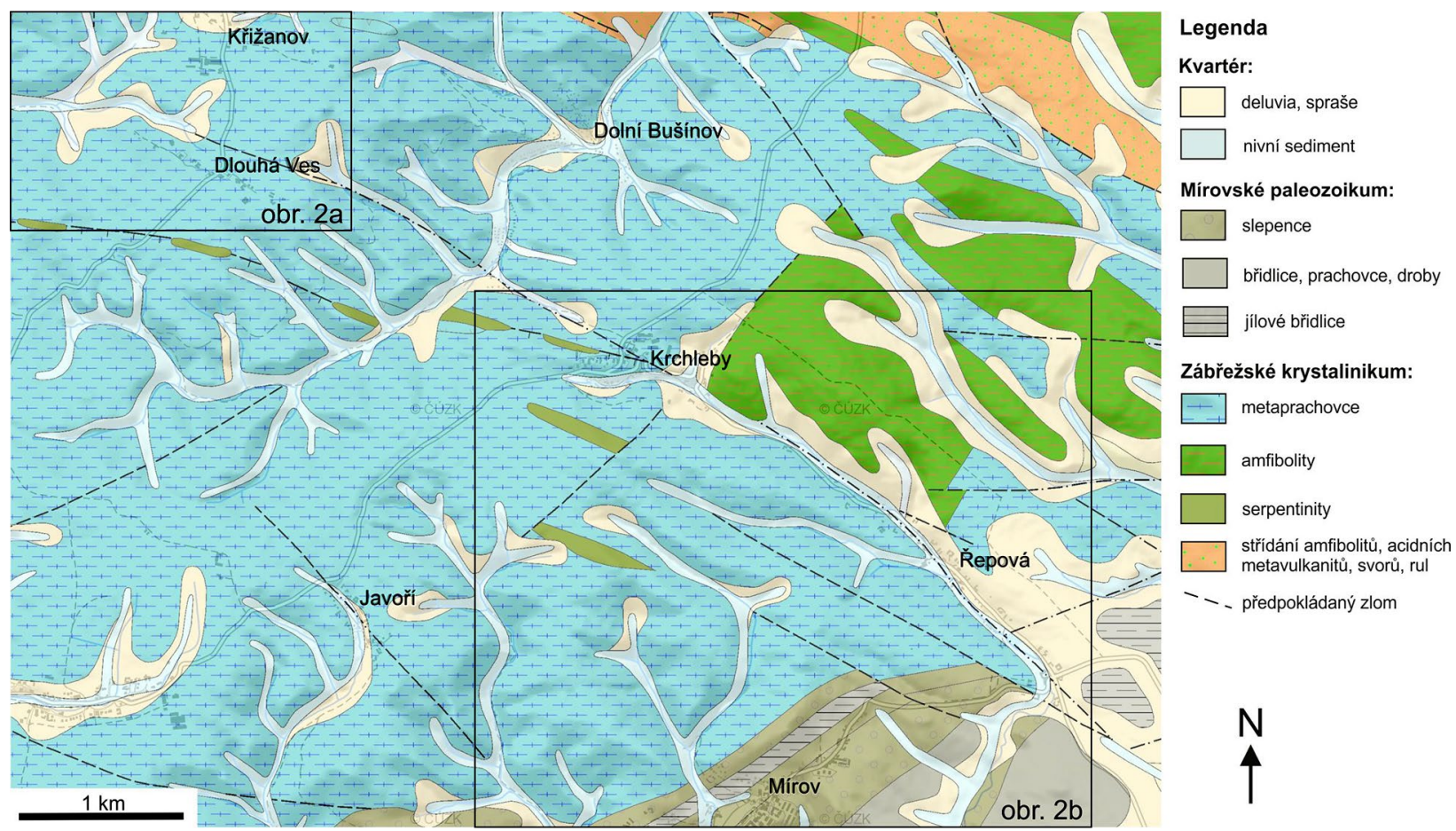

Obr. 1 Geologická pozice studované oblasti (upraveno z elektronické verze geologické mapy ČR 1:50 000; www.geology.cz). 


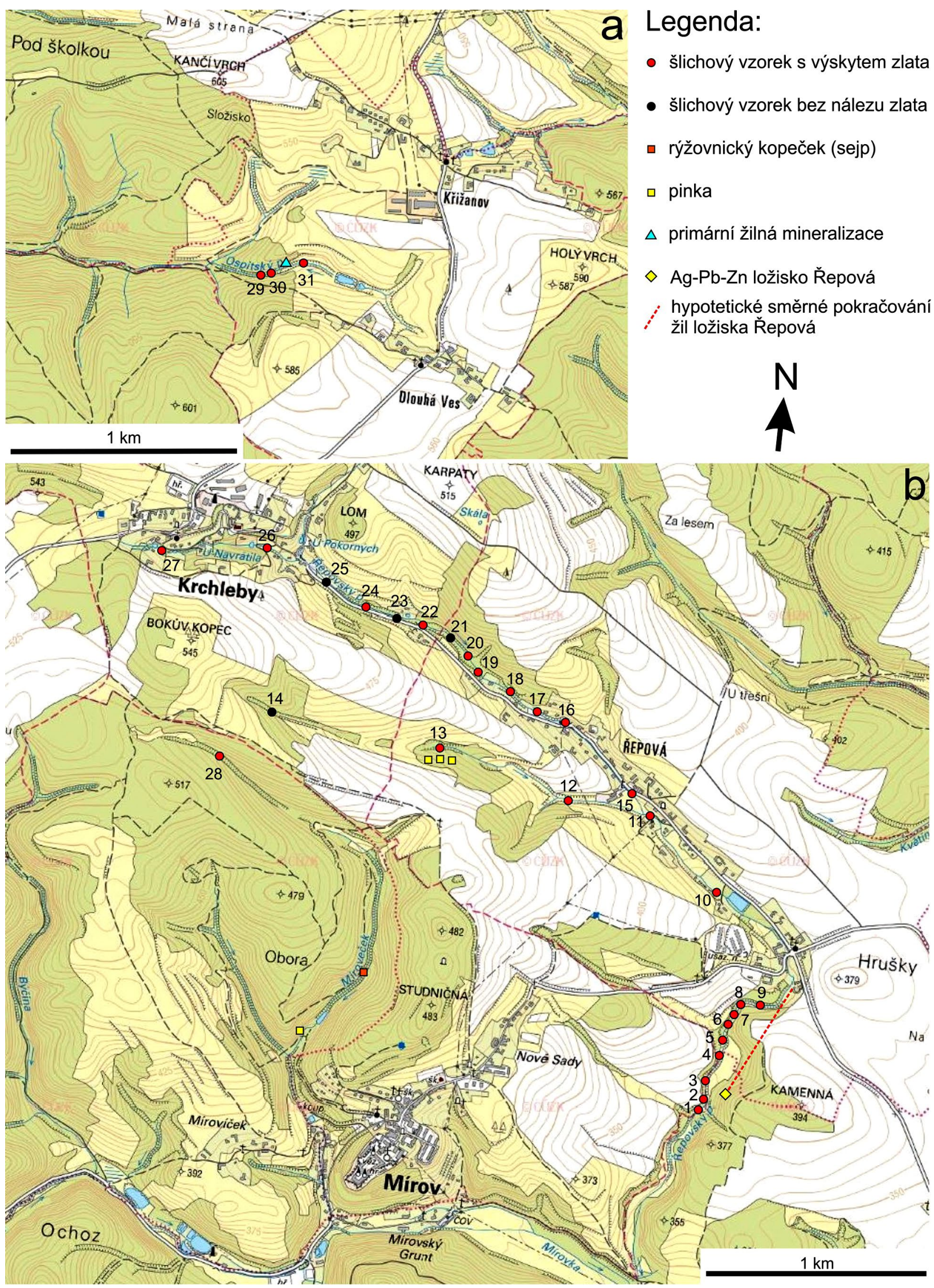

Obr. 2 Lokalizace odběrových mist, dochovaných terénních pozůstatků po hornické činnosti a rudních ložisek a výskytů (podkladová mapa převzata z webu Českého úřadu zeměměřického a katastrálního; www.cuzk.cz). 
řeno kvantitativní chemické složení vybraných fází ve vlnově disperzním (WDS) modu. Při bodových analýzách oxidických fází a karbonátů bylo použito urychlovací napětí $15 \mathrm{kV}$, proud svazku $10 \mathrm{nA}$ a defokusovaný elektronový svazek o průměru $2 \mu \mathrm{m}$. Při analýzách Mn-oxidu byly měřeny obsahy $\mathrm{Al}, \mathrm{Ba}, \mathrm{Ca}, \mathrm{Co}, \mathrm{Cu}, \mathrm{Cl}, \mathrm{Cr}, \mathrm{Cs}, \mathrm{F}, \mathrm{Fe}$, $\mathrm{K}, \mathrm{Mg}, \mathrm{Mn}, \mathrm{N}, \mathrm{Na}, \mathrm{Ni}, \mathrm{P}, \mathrm{Pb}, \mathrm{Rb}, \mathrm{Si}, \mathrm{Ti}, \mathrm{V}$ a Zn, při analýze $\mathrm{Cu}-\mathrm{Ca}-\mathrm{Mg}$ oxidu a karbonátů byly měřeny $\mathrm{Ba}, \mathrm{Ca}, \mathrm{Fe}$, $\mathrm{Mg}, \mathrm{Mn}, \mathrm{Na}, \mathrm{P}, \mathrm{S}, \mathrm{Si}, \mathrm{Sr}$ a Zn. Použité analytické čáry a standardy: albit (NaKa), almandin (AlKa, FeKa), apatit $(\mathrm{PK} \alpha)$, baryt $(\mathrm{BaL} \beta), \mathrm{BN}(\mathrm{NK} \alpha)$, celestin $(\mathrm{SK} \alpha, \mathrm{SrL} \beta)$, Co (CoKa), $\mathrm{Cr}_{2} \mathrm{O}_{3}$ (CrKa), Cs-sklo (CsLa), diopsid (MgKa),

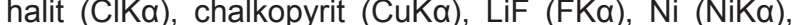
$\mathrm{Rb}-\mathrm{Ge}-$ sklo $(\mathrm{RbL \alpha})$, rodonit $(\mathrm{MnK \alpha})$, sanidin $(\mathrm{KK \alpha}), \mathrm{TiO}_{2}$ (TiKa), $\mathrm{V}(\mathrm{VK \alpha})$, vanadinit $(\mathrm{PbM \alpha})$, wollastonit (CaKa, SiKa), zinkit (ZnKa). Při bodových analýzách sulfidů, ryzích kovů a kupritu bylo použito urychlovací napětí $25 \mathrm{kV}$, proud svazku $60 \mathrm{nA}$ (pyrit), $20 \mathrm{nA}$ (ostatní sulfidy, slitiny $\mathrm{Cu}-\mathrm{Pb}-\mathrm{Zn}-\mathrm{Sb}$, kuprit), či $10 \mathrm{nA}$ (slitiny Au-Ag) a průměr elektronového svazku $2 \mu \mathrm{m}$ (pyrit), respektive $0.7 \mu \mathrm{m}$ (všechny ostatní fáze). Při analýzách pyritu byly měřeny obsahy $\mathrm{As}, \mathrm{Au}, \mathrm{Co}, \mathrm{Cu}, \mathrm{Fe}, \mathrm{Mn}, \mathrm{Ni}, \mathrm{Pb}, \mathrm{S}$ a $\mathrm{Sb}$, u slitin Au-Ag obsahy $\mathrm{Ag}, \mathrm{As}, \mathrm{Au}, \mathrm{Bi}, \mathrm{Cd}, \mathrm{Cl}, \mathrm{Cu}, \mathrm{Fe}, \mathrm{Ga}, \mathrm{Ge}$, $\mathrm{Hg}, \mathrm{Mn}, \mathrm{Pb}, \mathrm{S}, \mathrm{Sb}, \mathrm{Se}, \mathrm{Sn}, \mathrm{Te}$ a $\mathrm{Zn}$ a u všech ostatních
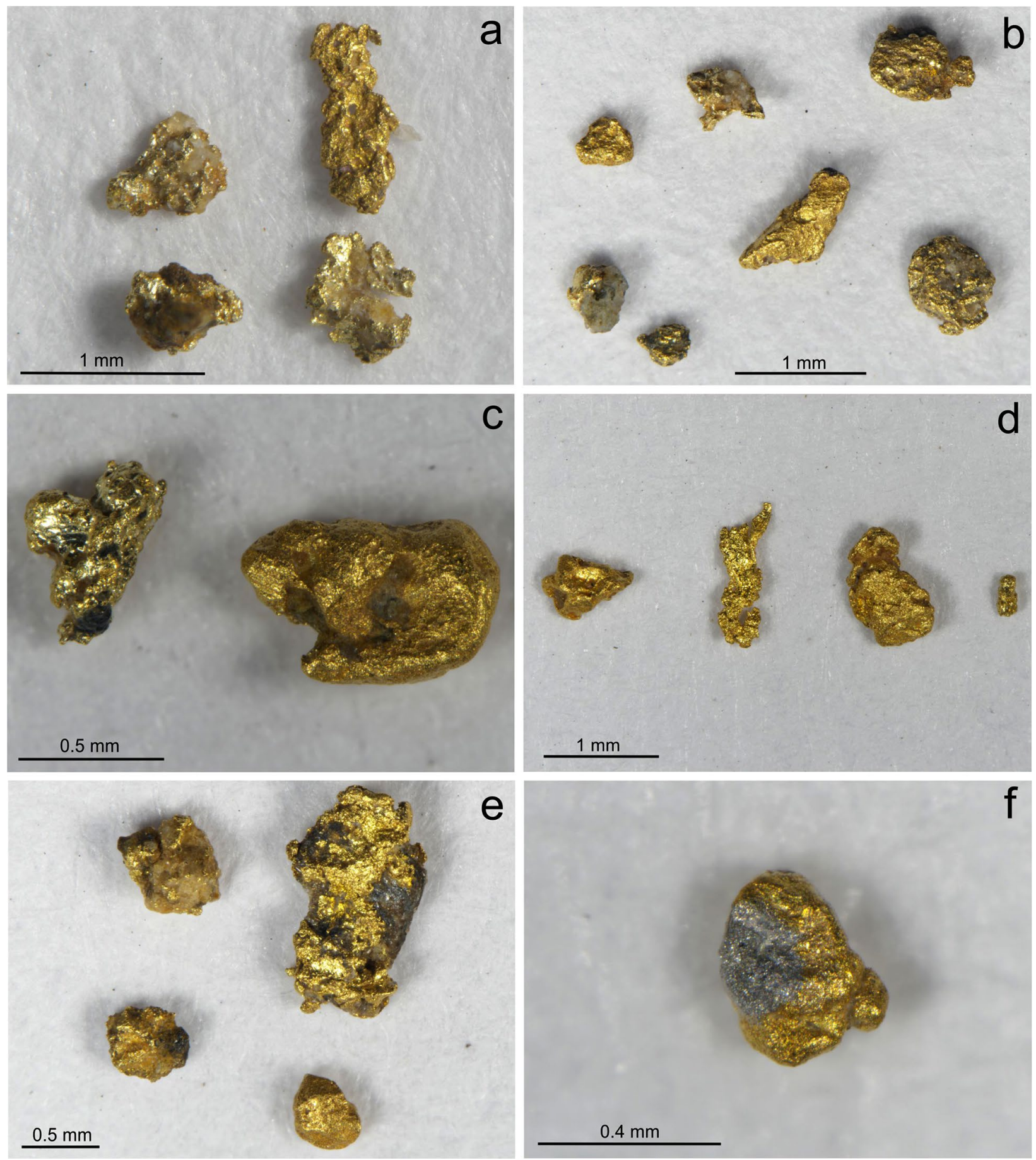

Obr. 3 Makroskopický vzhled studovaných aluviálních zlatinek z jednotlivých lokalit. a - Řepovský potok, lokalita č. 2+3; b - Řepovský potok, lokalita č. 8; c - Řepovský potok, lokalita č. 26; d-Míroveček, lokalita č. 28; e - Ospitský potok, lokalita č. 30+31; f- Ospitský potok, lokalita č. 29. Snímky J. Ulmanová. 
fází byly analyzovány vedle prvků uvedených pro slitiny Ag-Au i obsahy Co, In a Ni. Použité standardy a analytické čáry: $\mathrm{Ag}(\mathrm{AgL} \alpha), \mathrm{Au}(\mathrm{AuM \alpha}), \mathrm{Bi}_{2} \mathrm{~S}_{3}(\mathrm{BiM} \beta), \mathrm{CdTe}$ (CdLa), Co (CoKa), CuFes 2 (CuKa, SKa), FeS 2 (FeKa), GaAs (GaL $\alpha)$, Ge (GeLa), HgTe (HgLa), InAs (InL $\alpha)$, $\mathrm{Mn}(\mathrm{MnK \alpha}), \mathrm{NaCl}(\mathrm{ClK \alpha})$, NiAs (AsL $\beta$ ), Ni (NiKa), PbS (PbMa), PbSe (SeL $\beta), P b T e(T e L \alpha), \mathrm{Sb}_{2} \mathrm{~S}_{3}(\mathrm{SbL} \alpha), \mathrm{Sn}$ $(\mathrm{SnL} \alpha)$ a ZnS (ZnKa). Měrící časy na píku se pohybovaly většinou mezi 10 - 30 s, s výjimkou N (120 s) a Au v py- ritu (100 s). Měřící časy na pozadí trvaly polovinu času měření na píku. Načtená data byla přepočítána na hm. \% s použitím standardní PAP korekce (Pouchou, Pichoir 1985). Obsah kyslíku v kyslíkatých fázích byl dopočten ze stechiometrie. Obsahy výše uvedených měřených prvků, které nejsou uvedeny $v$ tabulkách, byly ve všech př́padech pod mezí stanovitelnosti. Detekční limit Au se při analýze pyritu za daných analytických podmínek pohyboval kolem cca 250 ppm.
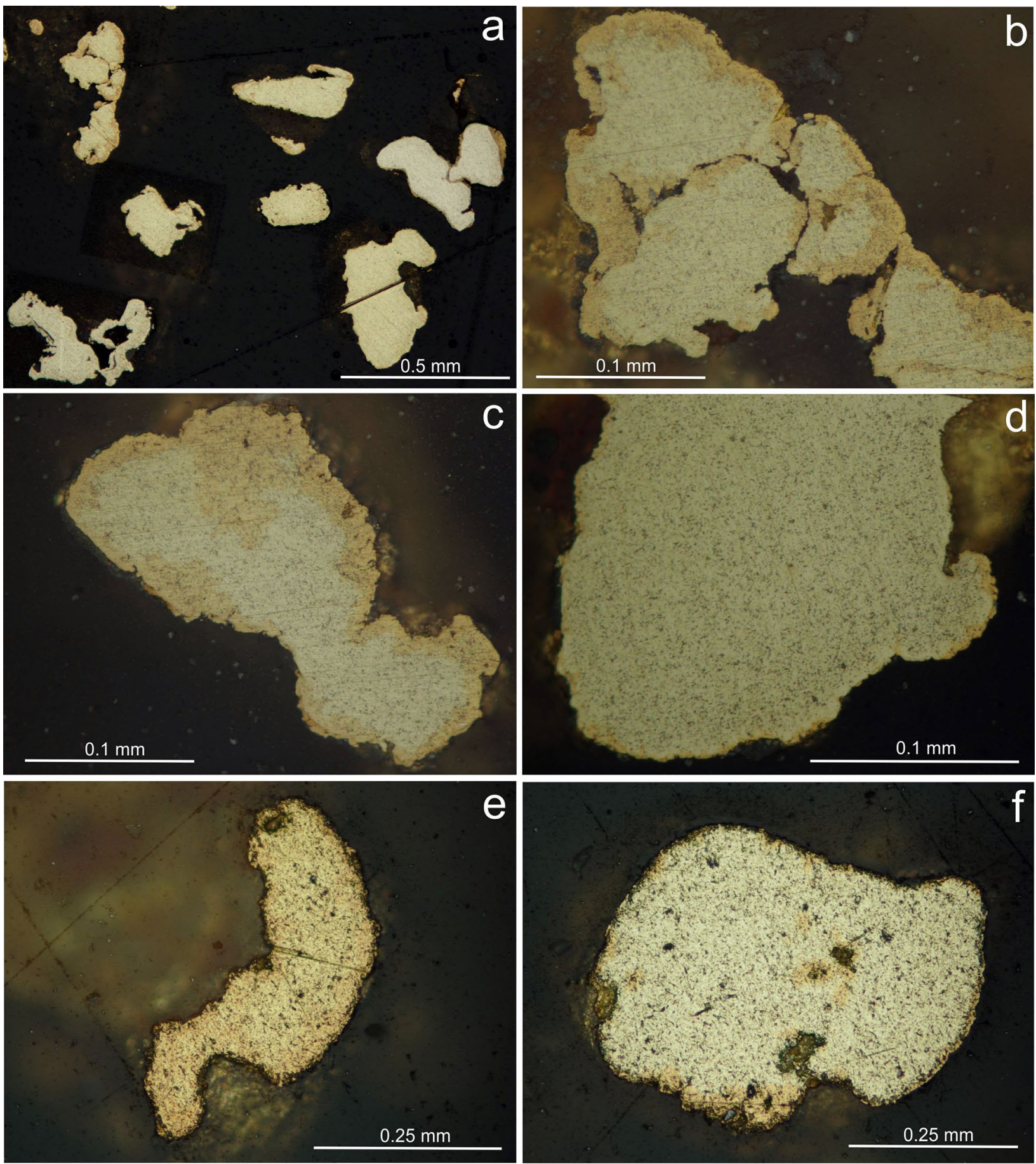

Obr. 4 Příklady vnitřní stavby studovaných aluviálních zlatinek v odraženém světle polarizačního mikroskopu. a - skupina zlatinek s variabilni ryzostí, Řepovský potok, lokalita č. 1; b - detail levé horní nedokonale sbalené zlatinky z obr. (a) s výrazně vyvinutým ryzejším lemem, Řepovský potok, lokalita č. 1; c - kompozičně homogenní zlatinka s výrazným ryzejším lemem, Řepovský potok, lokalita č. 1; d-detail kompozičně homogenní zlatinky z pravého dolního rohu obr. (a) s téměř chybějícím ryzejším okrajem, Řepovský potok, lokalita č. 1; e - zlatinka s nevýrazně vyvinutým ryzejším lemem, Míroveček, lokalita č. 28; f- zlatinka se slabě vyvinutým ryzejším lemem na okraji a drobnými ryzejšími doménami i uvnitř jádra, Ospitský potok, lokalita č. 30+31. Snímky Z. Dolníček. 


\section{Výsledky}

\section{Aluviální zlato}

Detailní šlichová prospekce sedimentů Řepovského potoka ukázala, že se zlato vyskytuje v celém studovaném úseku potoka od rudního ložiska Řepová až k prameni. Pouze na třech z celkem 24 odběrových míst nebyl výskyt zlata zaznamenán (obr. 2). Zlato bylo zjištěno i ve zvodnělé části údolí bezejmenného pravostranného přítoku Řepovského potoka, toliko na posledním odběrném místě v závěrné suché části údolí tohoto přítoku (lokalita č. 14; obr. 2) zlato zjištěno nebylo. Úspěšné byly i šlichovací zkoušky na horních tocích potoků Míroveček (bod č. 28) a Ospitský potok (body 29 - 31). Na potoku Míroveček byl při terénní rekognoskaci dokumentován i ojedinělý sejp (zsz. od vrcholu kopce Studničná; obr. 2).

Tabulka 1 Variace $v$ chemickém složení jednotlivých studovaných aluviálních zlatinek. Obsahy v at. \%, čísla v závorkách označuji počet analýz. Pomlčka ve sloupci lem - Au znamená, že ryzejši lem není př́tomen.

\begin{tabular}{|c|c|c|c|c|}
\hline poř. č. & lokalita & jádro - Au & jádro - Hg & lem - Au \\
\hline 1 & 1 & $57.8-57.9(4)$ & $3.7-4.0(2)$ & $91.5-93.7(2)$ \\
\hline 2 & 1 & $65.5-66.7(2)$ & $1.5-1.9(2)$ & - \\
\hline 3 & 1 & $60.0-60.3(2)$ & - & $96.1(1)$ \\
\hline 4 & 1 & $58.2-59.5(2)$ & - & $99.2(1)$ \\
\hline 5 & 1 & $67.6-71.2(2)$ & $0.7(1)$ & - \\
\hline 6 & 1 & $73.3-79.2(3)$ & $2.4(1)$ & - \\
\hline 7 & 1 & $42.8-46.1(2)$ & $4.0-4.2(2)$ & $91.9(1)$ \\
\hline 8 & 1 & $49.6-50.6(3)$ & $1.0-1.3(3)$ & - \\
\hline 9 & 1 & $91.9-99.8(2)$ & - & - \\
\hline 10 & 1 & $78.4-79.8(2)$ & $1.1-2.2(2)$ & - \\
\hline 11 & 1 & $58.8-60.3(4)$ & - & $92.2-94.7(3)$ \\
\hline 12 & 1 & $50.8-52.3(4)$ & - & - \\
\hline 13 & 1 & $28.1-30.3(3)$ & - & - \\
\hline 14 & 1 & $58.8-60.3(4)$ & - & $97.1(1)$ \\
\hline 15 & 1 & $30.8-45.5(5)$ & $0.1-2.0(3)$ & $92.3(1)$ \\
\hline 16 & 2 a 3 & $57.9-58.8(2)$ & $0.5-0.9(2)$ & - \\
\hline 17 & 2 a 3 & $40.9-51.8(3)$ & - & - \\
\hline 18 & 2 a 3 & $60.0-62.9(2)$ & $0.2-0.3(2)$ & $95.4(1)$ \\
\hline 19 & 2 a 3 & $93.3-96.4(6)$ & - & - \\
\hline 20 & 8 & $72.5-74.2(3)$ & $1.1-4.8(3)$ & - \\
\hline 21 & 8 & $51.8-53.0(3)$ & $3.7-5.1(3)$ & - \\
\hline 22 & 8 & $88.0-88.3(2)$ & - & $99.2(1)$ \\
\hline 23 & 8 & $47.7-56.4(2)$ & $1.1-1.2(2)$ & $97.8(1)$ \\
\hline 24 & 8 & $50.6-57.0(5)$ & $0.9-3.0(5)$ & - \\
\hline 25 & 13 & $90.4-91.3(3)$ & - & - \\
\hline 26 & 13 & $49.9-50.3(3)$ & - & - \\
\hline 27 & 13 & $63.8-65.5(6)$ & - & - \\
\hline 28 & 13 & $87.5-87.6(3)$ & - & - \\
\hline 29 & 13 & $83.9-84.5(3)$ & - & - \\
\hline 30 & 26 & $58.6-59.0(5)$ & - & $97.0-98.7(2)$ \\
\hline 31 & 27 & 64.6 (1) & - & $91.2-93.3(2)$ \\
\hline 32 & 27 & $70.8-73.9(3)$ & - & - \\
\hline 33 & 28 & 79.2 - $79.8(2)$ & - & $95.2-99.6(4)$ \\
\hline 34 & 28 & $85.7-87.9(8)$ & - & $98.5-99.0(2)$ \\
\hline 35 & 28 & $74.9-79.0(4)$ & - & - \\
\hline 36 & 28 & $67.4-75.3(3)$ & - & - \\
\hline 37 & 29 & $71.3-72.8(4)$ & - & - \\
\hline 38 & 30 a 31 & $71.9-72.5(2)$ & - & $96.6(1)$ \\
\hline 39 & 30 a 31 & $54.3-60.2(2)$ & - & 97.7 - $98.2(2)$ \\
\hline 40 & 30 a 31 & $88.6-90.6(5)$ & - & - \\
\hline 41 & 30 a 31 & $77.5-78.6(2)$ & - & - \\
\hline 42 & 30 a 31 & $31.1-32.2(4)$ & $0.2(1)$ & $91.4-97.1(3)$ \\
\hline
\end{tabular}

$\mathrm{Na}$ všech dokumentovaných potocích představuje zlato akcesorickou komponentu získaných šlichů. Z pěti pánví vyrýžovaného materiálu se obvykle získaji 1 - 2 zlatinky. Velikost nalezených zlatinek se pohybuje mezi 0.2 a $1.1 \mathrm{~mm}$, ojediněle dosahují některé zlatinky velikosti až $3 \mathrm{~mm}$. Jejich tvary jsou rozmanité, převažují však relativně ostrohranné a morfologicky členité, transportem málo opracované plíškovité či drátkovité typy nad dobře zaoblenými izometrickými zlatinkami (srov. obr. 3). Na první pohled zaujme i široká škála barevné variability zlatinek (světle až sytě žlutá; obr. 3), svědčící o variabilní ryzosti jejich povrchu. Světleji zbarvené zlatinky jsou zřetelně morfologicky členitější než sytě žluté typy (srov. obr. 3ae). Zvláštností jsou dvě poměrně dobře zaoblené sytěji žluté zlatinky vyrýžované na Ospitském potoce na lokalitě č. 29, které na sobě mají okrouhlé, šedě zbarvené skvrny (obr. 3f). Řada zlatinek obsahuje i větší nebo menší podíl nerudních minerálů bílé barvy a skelného lesku (obr. 3).

Studium vybraných 42 naleštěných zlatinek v polarizovaném světle odrazového mikroskopu a následně i $v$ elektronovém mikroskopu potvrdilo existenci značných rozdílů $\checkmark$ ryzosti různých zlatinek $\mathrm{i} v$ rámci jedné a téže odběrové lokality (obr. 4a). U necelé poloviny zlatinek Ize dále konstatovat prítomnost různě silného (většinou tenkého a neprůběžného) okrajového lemu s výrazně vyšší ryzostí, než má hlavní hmota zlatinky (obr. 4). Ojediněle (dva případy) byly nalezeny i výrazně ryzejší inkluze uvnitř zlatinky, které nejspíše představuji jenom záhyby nerovného povrchu, zachycené daným řezem nábrusu. Hlavní hmota zlatinek však žádnou výraznou vizuálně patrnou zonálnost obvykle nevykazuje (obr. 4). Typickým znakem je i velmi jemně porézní charakter kovu. Žádná kompoziční anomálie nebyla zjištěna ani $v$ prípadě zlatinky $s$ šedou skvrnou z lokality č. 29 (obr. 3f) - je však možné, že rovina nábrusu minula barevně anomální doménu. $Z$ analogie se zlatem z jiných oblastí Čech Ize předpokládat, že se pravděpodobně jedná o povlaky amalgamů, ale vyloučeny nejsou ani intermetalické sloučeniny s cínem (Malec 2002).

Podrobně bylo studováno chemické složení zlatinek. V závislosti na velikosti a pozorované kompoziční složitosti bylo $v$ každé zlatince zhotoveno 2 - 10 kvantitativních bodových mikrosondových analýz. Celkem bylo nově pořízeno 157 analýz. Variace $v$ chemismu jednotlivých zlatinek jsou prezentovány $v$ tabulce 1 , reprezentativní príklady analýz jsou uvedeny $v$ tabulkách 2 a 3 a graficky jsou variace $v$ chemismu aluviálního zlata ze všech tři potoků ilustrovány na obrázku 5. Získaný datový soubor 
dokládá velmi širokou variabilitu chemismu aluviálního zlata ze všech studovaných vodních toků. Poněkud užší rozsah chemismu, zjištěný pro Míroveček (obr. 5b), může být důsledkem velmi malého počtu proměřených zlatinek ( $\mathrm{n}=4$; tab. 1).

Obsah zlata $v$ hlavní hmotě zlatinek kolísá mezi 28.1 a 99.8 at. \% (tab. 1). Klasifikačně jde tedy většinou o zla- to, méně často i o zlatnaté stříbro (obr. 5). Při takové variabilitě je však pozoruhodná skutečnost, že $v$ rámci konkrétní zlatinky je ryzost hlavní hmoty až na několik výjimek velice homogenní, s rozsahy nepřesahujícími 3 at. $\%$ (tab. 1). Vedle zlata a stříbra byly v hlavní hmotě části zlatinek z lokalit č. 1, 2+3 a 8 naměřeny i zvýšené obsahy rtuti (0.1 - 5.1 at. \%), zatímco na ostatních odběrových

Tabulka 2 Příklady chemického složení aluviálních zlatinek z Řepovského potoka. Obsahy v hm. \%, hodnoty apfu jsou vypočitány na základ 1 atomu kovů na vzorcovou jednotku.

\begin{tabular}{lrrrrrrrrrrrrrr}
\hline An. č. & 1 & 2 & 3 & 4 & 5 & 6 & 7 & 8 & 9 & 10 & 11 & 12 & 13 & 14 \\
Lokalita & 1 & 1 & $2+3$ & 8 & 1 & $2+3$ & 8 & 8 & $2+3$ & 13 & 8 & 1 & 26 & 8 \\
Pozice & jádro & jádro & jádro & jádro & jádro & jádro & jádro & jádro & jádro & lem & lem & lem & lem & lem \\
\hline $\mathrm{Au}$ & 42.34 & 54.17 & 56.22 & 65.09 & 70.36 & 75.01 & 80.98 & 82.10 & 97.79 & 91.19 & 93.59 & 94.75 & 99.65 & 100.23 \\
$\mathrm{Ag}$ & 59.40 & 44.34 & 43.83 & 28.05 & 25.39 & 23.72 & 13.45 & 13.39 & 1.91 & 9.40 & 6.71 & 4.77 & 0.72 & 0.10 \\
$\mathrm{Cu}$ & 0 & 0 & 0.10 & 0 & 0 & 0.09 & 0 & 0 & 0 & 0 & 0.08 & 0 & 0 & 0.09 \\
$\mathrm{Hg}$ & 0 & 2.79 & 0 & 6.40 & 4.62 & 0.33 & 5.47 & 3.91 & 0 & 0 & 0 & 0 & 0 & 0 \\
$\mathrm{Cd}$ & 0.06 & 0.06 & 0 & 0 & 0 & 0 & 0 & 0 & 0 & 0 & 0 & 0.06 & 0 & 0 \\
$\mathrm{Fe}$ & 0 & 0 & 0.23 & 0.08 & 0 & 0.10 & 0.06 & 0.07 & 0.05 & 0 & 0.06 & 0 & 0 & 0.09 \\
$\mathrm{Ga}$ & 0 & 0 & 0 & 0 & 0.16 & 0 & 0 & 0 & 0 & 0 & 0 & 0 & 0 & 0 \\
$\mathrm{~S}$ & 0 & 0 & 0.07 & 0 & 0 & 0.06 & 0 & 0 & 0 & 0 & 0 & 0 & 0 & 0 \\
$\mathrm{Te}$ & 0 & 0.08 & 0 & 0 & 0 & 0 & 0 & 0 & 0 & 0 & 0 & 0 & 0 & 0 \\
$\mathrm{Cl}$ & 0.14 & 0.07 & 0.20 & 0.16 & 0.09 & 0.12 & 0.14 & 0.12 & 0 & 0 & 0.09 & 0 & 0 & 0 \\
\hline Celkem & 101.94 & 101.51 & 100.64 & 99.78 & 100.63 & 99.43 & 100.10 & 99.58 & 99.75 & 100.59 & 100.52 & 99.58 & 100.37 & 100.51 \\
\hline $\mathrm{Au}$ & 0.281 & 0.393 & 0.409 & 0.530 & 0.578 & 0.629 & 0.729 & 0.742 & 0.964 & 0.842 & 0.880 & 0.915 & 0.987 & 0.992 \\
$\mathrm{Ag}$ & 0.719 & 0.587 & 0.583 & 0.417 & 0.381 & 0.363 & 0.221 & 0.221 & 0.034 & 0.158 & 0.115 & 0.084 & 0.013 & 0.002 \\
$\mathrm{Cu}$ & 0 & 0 & 0.002 & 0 & 0 & 0.002 & 0 & 0 & 0 & 0 & 0.002 & 0 & 0 & 0.003 \\
$\mathrm{Hg}$ & 0 & 0.020 & 0 & 0.051 & 0.037 & 0.003 & 0.048 & 0.035 & 0 & 0 & 0 & 0 & 0 & 0 \\
$\mathrm{Cd}$ & 0.001 & 0.001 & 0 & 0 & 0 & 0 & 0 & 0 & 0 & 0 & 0 & 0.001 & 0 & 0 \\
$\mathrm{Fe}$ & 0 & 0 & 0.006 & 0.002 & 0 & 0.003 & 0.002 & 0.002 & 0.002 & 0 & 0.002 & 0 & 0 & 0.003 \\
$\mathrm{Ga}$ & 0 & 0 & 0 & 0 & 0.004 & 0 & 0 & 0 & 0 & 0 & 0 & 0 & 0 & 0 \\
\hline $\mathrm{Me} \mathrm{sum}$ & 1.000 & 1.000 & 1.000 & 1.000 & 1.000 & 1.000 & 1.000 & 1.000 & 1.000 & 1.000 & 1.000 & 1.000 & 1.000 & 1.000 \\
\hline $\mathrm{S}$ & 0 & 0 & 0.003 & 0 & 0 & 0.003 & 0 & 0 & 0 & 0 & 0 & 0 & 0 & 0 \\
$\mathrm{Te}$ & 0 & 0.001 & 0 & 0 & 0 & 0 & 0 & 0 & 0 & 0 & 0 & 0 & 0 & 0 \\
$\mathrm{Cl}$ & 0.005 & 0.003 & 0.008 & 0.007 & 0.004 & 0.006 & 0.007 & 0.006 & 0 & 0 & 0.005 & 0 & 0 & 0 \\
\hline $\mathrm{Ansum}$ & 0.005 & 0.004 & 0.011 & 0.007 & 0.004 & 0.009 & 0.007 & 0.006 & 0 & 0 & 0.005 & 0 & 0 & 0 \\
\hline
\end{tabular}

Tabulka 3 Př́klady chemického složení aluviálních zlatinek z Mírovečku a Ospitského potoka a primárního zlata od Dlouhé Vsi (PDV). Obsahy v hm. \%, hodnoty apfu jsou vypočitány na základ 1 atomu kovů na vzorcovou jednotku. \begin{tabular}{llllllllllllll} 
An. č. & 1 & 2 & 3 & 4 & 5 & 6 & 7 & 8 & 9 & 10 & 11 & 12 & 13 \\
\hline
\end{tabular} $\begin{array}{lllllllllllllll}\text { Lokalita } & 28 & 28 & 28 & 28 & 28 & 29 & 30+31 & 30+31 & 30+31 & 30+31 & 29 & \text { PDV } & \text { PDV } & \text { PDV }\end{array}$ Pozice jádro jádro jádro lem lem jádro jádro jádro jádro jádro lem jádro jádro jádro

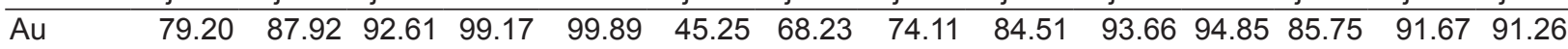

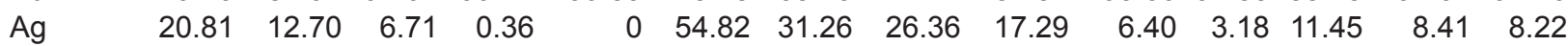

\begin{tabular}{|c|c|c|c|c|c|c|c|c|c|c|c|c|c|c|}
\hline $\mathrm{Cu}$ & 0 & 0 & 0.12 & 0.14 & 0 & 0 & 0 & 0.13 & 0.07 & 0 & 0 & 0 & 0 & 0.07 \\
\hline $\mathrm{Hg}$ & 0 & 0 & 0 & 0 & 0 & 0.31 & 0 & 0 & 0 & 0 & 0 & 0 & 0 & 0 \\
\hline $\mathrm{Fe}$ & 0.08 & 0.06 & 0.09 & 0.12 & 0.11 & 0 & 0.09 & 0.12 & 0 & 0.09 & 0 & 0 & 0 & \\
\hline$S$ & 0.03 & 0 & 0 & 0.06 & 0.04 & 0 & 0 & 0.10 & 0 & 0 & 0 & 0 & 0 & \\
\hline $\mathrm{Te}$ & 0 & 0 & 0 & 0 & 0 & 0.19 & 0 & 0 & 0 & 0 & 0 & 0 & 0 & \\
\hline C & 0.13 & 0.08 & 0.07 & 0 & 0 & 0 & 0.15 & 0.16 & 0 & 0 & 0 & 0 & 0 & \\
\hline
\end{tabular}

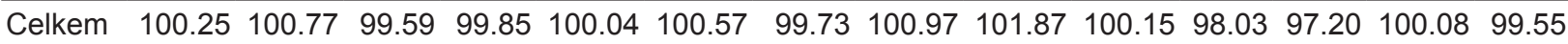

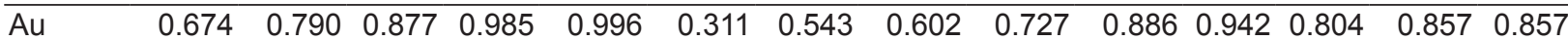
$\begin{array}{llllllllllllllll}\mathrm{Ag} & 0.323 & 0.208 & 0.116 & 0.007 & 0 & 0.687 & 0.454 & 0.391 & 0.271 & 0.111 & 0.058 & 0.196 & 0.143 & 0.141\end{array}$

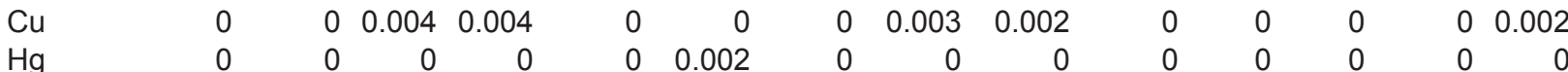

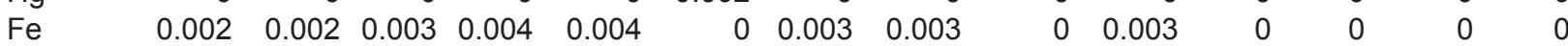
$\begin{array}{lllllllllllllll}\text { Me sum } & 1.000 & 1.000 & 1.000 & 1.000 & 1.000 & 1.000 & 1.000 & 1.000 & 1.000 & 1.000 & 1.000 & 1.000 & 1.000 & 1.000\end{array}$

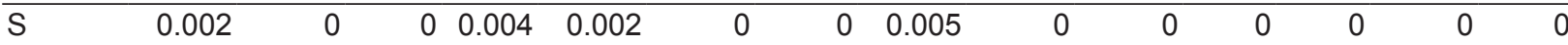

\begin{tabular}{|c|c|c|c|c|c|c|c|c|c|c|}
\hline \multirow[t]{2}{*}{ Гe } & & 0 & 0 & 0 & 0 & 0.002 & 0 & 0 & 0 & \\
\hline & 0.006 & 0.004 & 0.004 & 0 & 0 & 0 & 0.007 & 0.007 & 0 & \\
\hline nsum & 0.008 & 0.004 & 0.004 & 0.004 & 0.002 & 0.002 & 0.007 & 0.012 & 0 & ( \\
\hline
\end{tabular}



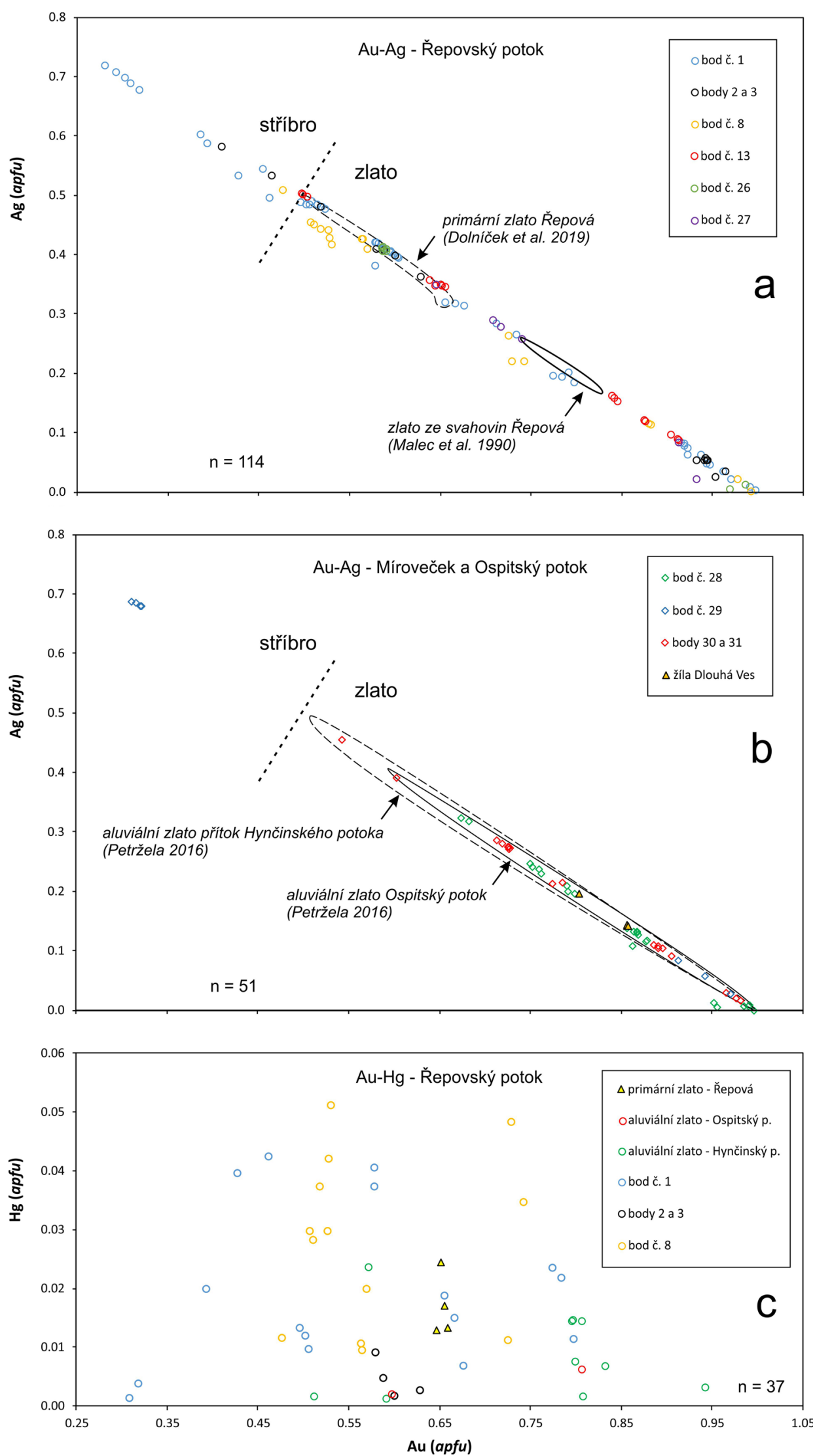

Obr. 5 Variace $v$ chemismu aluviálního a primárního zlata na studovaných lokalitách a jejich porovnání s publikovanými údaji. a - diagram Au-Ag, Řepovský potok; b - diagram Au-Ag, Míroveček a Ospitský potok; c - diagram Au-Hg, Řepovský potok (vyneseny jsou pouze analýzy s nenulovým obsahem $\mathrm{Hg}$ ). Srovnávací data pro primární zlato z rudního ložiska Řepová byla převzata z Dolníčka et al. (2019), data pro aluviálni zlato z Ospitského potoka a z bezejmenného přitoku Hynčinského potoka z Petržely (2016). bodech byla rtut' vždy pod mezí stanovitelnosti (tab. 1). Zvýšené obsahy rtuti nijak nekorelují s ryzostí zlata (obr. 5c). Obsahy dalších složek ( $\mathrm{Fe}, \mathrm{Cu}$, $\mathrm{Cd}, \mathrm{Ga}, \mathrm{S}, \mathrm{Te}, \mathrm{Cl}$ ) byly typicky naměřeny jen poměrně vzácně, nesystematicky a obvykle jen ve velmi malých koncentracích ( $\leq 0.27 \mathrm{hm}$. \%), ojediněle byly zaznamenány $\mathrm{i}$ výrazněji zvýšené obsahy Fe (až 1.4 hm. \%).

Okrajový lem je na zlatinkách vždy tvořen vysoce ryzím zlatem (91.2 až 99.6 at. \%; tab. 1). Vedlejší komponentou je vždy jen stríbro, zatímco rtut' nebyla v ryzejších lemech nikdy naměřena - a to ani $v$ těch zlatinkách, jejichž střední části rtut' obsahují. Vznik ryzejších lemů souvisí s působením exogenních vlivů spojeným s vyloužením stříbra (např. Morávek et al. 1992; Krupp, Weiser 1992).

\section{Doprovodné fáze}

Vedle kovové Au-Ag fáze obsahují vyrýžované zlatinky $v$ príibližně polovině prípadů i další minerální fáze. Pomocí EDS spekter byl identifikován chlorit, muskovit, křemen, alkalické živce, biotit, jílové minerály, limonit a Fe-S-K-O fáze patrně blízká jarositu. Nejčastěji se zlato prorůstá s relativně jemnozrnnými (velikost zrn maximálně kolem $100-150 \mu \mathrm{m}$ ) polyminerálními agregáty tvořenými hlavně fylosilikáty (muskovit, chlorit, biotit, chloritizovaný biotit, illit, minerál z kaolinitové skupiny, smektit) a živci (hlavně K-živec, méně albit, ojediněle i Na-K živec), akcesoricky i křemenem. Méně časté jsou asociace zlata s monominerálními agregáty chloritu, muskovitu či K-živce. Chemismus chloritu je podle EDS spekter vzorek od vzorku silně variabilní (Fe chlorit, Fe-Mg chlorit, Mg-Fe chlorit, ojediněle i Fe-Zn chlorit). Jako chlorit po biotitu jsou interpretovány chlori- 
ty se zvýšenými obsahy K a Ti. Nikdy nebyla zjištěna asociace zlata s monominerálním křemenem.

Další minerální fáze byly zjištěny ve šlichách v podobě samostatných zrn. Běžný je zejména limonit, často uzavírající relikty pyritu a někdy i zrna supergenního barytu (obr. 6a). Nezvětralý pyrit je další obvyklou, leč minoritní složkou šlichů. Orientační studium chemického složení pyritu z Ospitského potoka ukázalo uniformní obsahy Au mezi 0.05 a 0.06 hm. \%, Pb mezi 0.12 a 0.14 hm. \% a Co mezi 0.02 a $0.04 \mathrm{hm}$. \%. Částečně limonitizovaný pyrit z klastů křemenné žiloviny, nalezených $v$ řečišti Řepovského potoka na lokalitě č. 1 , měl obsahy Au mezi 0.04 a 0.06 hm. \%, Pb mezi 0.10 a 0.18 hm. \%, Co mezi 0.05 a $0.45 \mathrm{hm}$. \% a Ni mezi 0.0 a 0.64 hm. \%. V Ospitském potoce byl $v$ asociaci s porézním pyritem ojediněle nalezen i markazit. Z lokality č. 1 na Řepovském potoce pochází nález Mn-oxidu se složením blízkým kryptomelanu se zvýšeným podílem hollanditové komponenty (tab. 4). Na Řepovském potoce byl na lokalitách č. 1, 2+3 a 15 sporadicky zjištěn cinabarit $v$ podobě jasně červených zrnek o velikosti do $0.5 \mathrm{~mm}$. Identifikace byla ověřena analýzami na mikrosondě, při nichž byly vedle $\mathrm{Hg}$ a $\mathrm{S}$ zjištěny i minoritní obsahy $\mathrm{Zn}(\max .0 .6 \mathrm{hm}$. \%) a Ag (max. 0.16 hm. \%). Na týchž lokalitách byl vyrýžován i červený ku- prit srůstající s ryzí mědí. Ve vzorku z lokality č. 1, který obsahoval i nepatrné relikty chalkopyritu (obr. 6b), nebyly WDS analýzou ryzí mědi zjištěny žádné príměsi, zatímco v kupritu byly prítomny zvýšené obsahy rtuti $(0.19-0.71$ hm. \% HgO) a olova (0.10- $0.70 \mathrm{hm}$. \% PbO).

Problematické je jedno zrno s kupritem a ryzí mědí z lokality č. 15 (obr. 6c), u něhož nelze vyloučit antropogenní původ. Vedle zmiňovaných fází obsahuje i inkluze oxidu cínu, druhý oxid mědi ( $\mathrm{CuO})$ a v odrazovém mikroskopu velmi silně anizotropní Cu-Ca-Mg oxidickou fázi $\mathrm{s}$ empirickým vzorcem $\left(\mathrm{Cu}_{0.86} \mathrm{Ca}_{0.12} \mathrm{Mg}_{0.12}\right)_{\Sigma=1.00} \mathrm{O}_{1.00}$ (viz tab. 4).

Jednoznačně antropogenního původu jsou částice různých kovových slitin, které byly ve velké míre vyrýžovány na lokalitě č. 26 a v menším množství i na lokalitě č. 15. Vedle částic kovového železa (někdy s obsahem Mn) byly zjištěny i částice chemicky čisté ryzí mědi a kuličky ferosilicia, které mají často instruktivně vyvinuté textury odmíšení slitin s různým složením. Dále byly relativně často identifikovány texturně komplikované částice slitin bohatých mědí. Základní matrice těchto slitin se složením bohatým mědí či mědí a zinkem charakteristicky obsahuje hojné drobné vyloučeniny (někdy krystalograficky zákonitě orientované; obr. $6 \mathrm{~d}$ ) bohatší cínem, kolem nichž
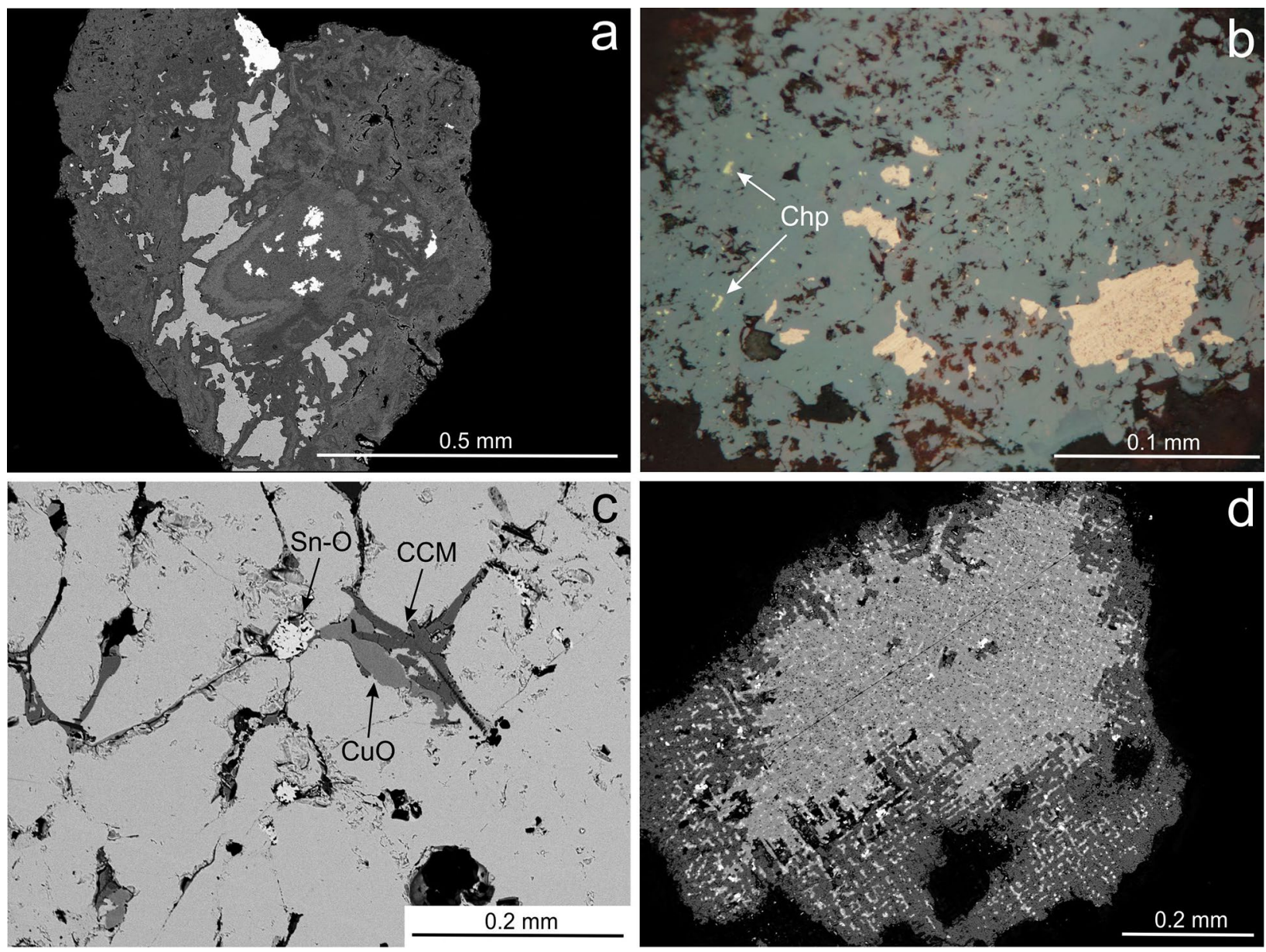

Obr. 6 Přiklady doprovodných fází ze získaných šlichů. a - kompozičně zonální limonit (nejtmavší), uzavírající relikty pyritu (šedý) a supergenní baryt (billý). Ospitský potok, lokalita č. 30+31, BSE obraz. b - kuprit (šedý), uzavírající ryzí měd' (rưžová) a drobné relikty chalkopyritu (Chp). Řepovský potok, lokalita č. 1, odražené světlo. c - kuprit (světle šedá základni masa), uzavírající inkluze oxidu cínu (Sn-O), druhého oxidu mědi (CuO) a Cu-Ca-Mg-O fáze (CCM). Řepovský potok, lokalita č. 15, BSE obraz. d-tmavými supergenními produkty silně zatlačovaná částice kovové Cu-Zn-Sn slitiny, jejiž základní matrice obsahuje krystalograficky orientované drobné vyloučeniny bohatší cínem (poněkud světlejší) a misty i větší inkluze tvořené olovem (bílé). Řepovský potok, lokalita č. 26, BSE obraz. Všechny snímky Z. Dolníček. 
bývá ještě vyvinut lem s přechodným složením. Průběžnými minoritními komponentami těchto $\mathrm{Cu}-\mathrm{Zn}-\mathrm{Sn}$ slitin je i antimon (0.13 - $0.72 \mathrm{hm} . \%)$, nikl (0.13 - $0.32 \mathrm{hm} . \%)$ a indium (0.06 - $0.20 \mathrm{hm}$. \%; tab. 5). Cu-Zn-Sn slitiny někdy obsahují i drobné inkluze olova (obr. 6d). Další vyrýžované kovové částice byly tvořeny čistým olovem, často silně zatlačovaným supergenními produkty. Ojediněle se vyskytla i samostatná zrnka tvořená čistým cínem a oxidem olova se složením odpovídajícím klejtu (PbO).

Tabulka 4 Chemické složení hollanditu (Hol) a oxidické Cu-Ca-Mg fáze (CCM), vyrýžovaných z Repovského potoka. Obsahy oxidu $v \mathrm{hm}$. \%, hodnoty apfu jsou vypočitány na bázi 16 atomů kyslíku a 9 kationtů (hollandit), resp. 1 atomu kyslíku (Cu-Ca-Mg oxid).

\begin{tabular}{|c|c|c|c|c|c|}
\hline An. č. & 1 & 2 & 3 & 4 & 5 \\
\hline Fáze & $\mathrm{Hol}$ & $\mathrm{Hol}$ & $\mathrm{Hol}$ & $\mathrm{CCM}$ & $\mathrm{CCM}$ \\
\hline $\mathrm{P}_{2} \mathrm{O}_{5}$ & 0 & 0 & 0 & 0.23 & 0.10 \\
\hline $\mathrm{SiO}_{2}$ & 0.43 & 0.48 & 0.47 & 0 & 0 \\
\hline $\mathrm{MnO}_{2}$ & 75.59 & 74.47 & 73.08 & & \\
\hline $\mathrm{Al}_{2} \mathrm{O}_{3}$ & 0.79 & 1.46 & 1.66 & & \\
\hline $\mathrm{MgO}$ & 0 & 0 & 0 & 6.68 & 6.52 \\
\hline $\mathrm{MnO}$ & 5.50 & 4.12 & 2.76 & 0 & 0 \\
\hline $\mathrm{FeO}$ & 0.62 & 1.25 & 2.85 & 0.17 & 0.14 \\
\hline $\mathrm{CoO}$ & 0.20 & 0.09 & 0.10 & 0 & 0 \\
\hline $\mathrm{CuO}$ & 0 & 0 & 0 & 84.91 & 84.24 \\
\hline $\mathrm{PbO}$ & 0 & 0 & 0.49 & 0 & 0 \\
\hline $\mathrm{CaO}$ & 0.52 & 0.45 & 0.50 & 8.50 & 9.08 \\
\hline $\mathrm{BaO}$ & 3.24 & 3.31 & 2.98 & 0 & 0 \\
\hline $\mathrm{K}_{2} \mathrm{O}$ & 3.39 & 3.30 & 3.19 & & \\
\hline $\mathrm{Na}_{2} \mathrm{O}$ & 0.14 & 0.29 & 0.17 & 0 & 0 \\
\hline Celkem & 90.42 & 89.22 & 88.25 & 100.26 & 99.98 \\
\hline $\mathrm{P}^{5+}$ & 0 & 0 & 0 & 0.002 & 0.001 \\
\hline $\mathrm{Si}^{4+}$ & 0.059 & 0.067 & 0.066 & 0 & 0 \\
\hline $\mathrm{Mn}^{4+}$ & 7.193 & 7.145 & 7.106 & & \\
\hline $\mathrm{Al}^{3+}$ & 0.128 & 0.239 & 0.275 & & \\
\hline $\mathrm{Mg}^{2+}$ & 0 & 0 & 0 & 0.119 & 0.117 \\
\hline $\mathrm{Mn}^{2+}$ & 0.641 & 0.484 & 0.329 & 0 & 0 \\
\hline $\mathrm{Fe}^{2+}$ & 0.071 & 0.145 & 0.335 & 0.002 & 0.001 \\
\hline $\mathrm{Co}^{2+}$ & 0.022 & 0.010 & 0.011 & 0 & 0 \\
\hline $\mathrm{Cu}^{2+}$ & 0 & 0 & 0 & 0.765 & 0.763 \\
\hline $\mathrm{Pb}^{2+}$ & 0 & 0 & 0.019 & 0 & 0 \\
\hline $\mathrm{Ca}^{2+}$ & 0.077 & 0.067 & 0.075 & 0.109 & 0.117 \\
\hline $\mathrm{Ba}^{2+}$ & 0.175 & 0.180 & 0.164 & 0 & 0 \\
\hline $\mathrm{K}^{+}$ & 0.595 & 0.584 & 0.573 & & \\
\hline $\mathrm{Na}^{+}$ & 0.037 & 0.078 & 0.046 & 0 & 0 \\
\hline Catsum & 9.000 & 9.000 & 9.000 & 0.997 & 0.998 \\
\hline
\end{tabular}

Tabulka 5 Přiklady chemického složení základní matrice vyrýžovaných Cu-Zn-Sn slitin (analýzy 1 - 3) a cínem bohatších domén (an. 4 - 6). Obsahy $v$ hm. \%.

\begin{tabular}{lrrrrrr}
\hline An. č. & 1 & 2 & 3 & 4 & 5 & 6 \\
\hline $\mathrm{Cu}$ & 78.53 & 85.64 & 93.19 & 83.59 & 63.87 & 68.32 \\
$\mathrm{Zn}$ & 19.57 & 10.31 & 3.36 & 0.31 & 14.78 & 4.87 \\
$\mathrm{Sn}$ & 0.41 & 1.14 & 2.07 & 13.49 & 17.02 & 23.62 \\
$\mathrm{Sb}$ & 0 & 0 & 0 & 0.44 & 0.72 & 0.36 \\
$\mathrm{~Pb}$ & 0 & 0 & 0 & 0 & 1.47 & 0.15 \\
$\mathrm{Fe}$ & 0.48 & 2.02 & 0.11 & 0 & 0.13 & 0.49 \\
$\mathrm{Ni}$ & 0.14 & 0.29 & 0.16 & 0.16 & 0.17 & 0.32 \\
$\mathrm{In}$ & 0.07 & 0.09 & 0.07 & 0.07 & 0.11 & 0.09 \\
\hline Celkem & 99.20 & 99.49 & 98.96 & 98.06 & 98.27 & 98.22 \\
\hline
\end{tabular}

\section{Primární zlato}

Rýžovnické pokusy zahrnující svahové sedimenty a nadrcené úlomky nalezených křemenných žil a pevných hornin byly z pohledu výskytu zlata všude negativní. Negativní výsledek mělo i šlichování materiálu obvalů drobných pinek, zjištěných na březích Mírovečku (zjz. od vrcholu kopce Studničná; obr. 2) a pravostranného přítoku Řepovského potoka (u lokality č. 13; obr. 2).

Jediná „primární“ zlatinka byla získána jen z nově zjištěného drobného výskytu žilné hydrotermální mineralizace $v$ zářezu Ospitského potoka u Dlouhé Vsi (obr. 2). Výplň žily je zde tvořena zejména drcenou horninou, stmelenou karbonátem dolomit-ankeritové řady a sideritem s ojedinělými vtroušeninami obecných sulfidů (pyrit, galenit, sfalerit, chalkopyrit, pyrhotin, arzenopyrit). Zlatinka sytě žluté barvy byla nalezena v těžkém podílu, získaném po šlichování rozdrcené žiloviny, obsahující jak hydrotermální minerály, tak úlomky okolních hornin. Po zalití do nábrusu a naleštění bylo možno jak v odraženém světle, tak na BSE snímku z elektronového mikroskopu konstatovat absenci jakékoliv chemické zonálnosti. Čtyři provedené WDS analýzy ukázaly obsahy Au mezi 80.4 a 85.8 at. \% (tab. 3, obr. 5b). Kromě stříbra nebyly zjištěny žádné významnější obsahy dalších prvků. Chemické složení pyritu z této mineralizace je velice blízké výše charakterizovaným pyritům ze šlichů. Obsahy Au jsou mezi 0.05 a 0.08 hm. \%, Pb mezi 0.10 a 0.27 hm. \%, Co mezi 0.02 a $0.71 \mathrm{hm}$. \% a Ni mezi 0.0 a 1.09 hm. \%. Galenit (místy zatlačovaný anglesitem) má zajímavé chemické složení (tab. 6), se zvýšenými obsahy $\mathrm{Bi}(\sim 1 \mathrm{hm}$. \%), Se ( 0.8 hm. \%), Ag ( 0.3 hm. \%), TI ( 0.2 hm. \%) a Te $(\sim 0.2 \mathrm{hm} . \%)$. Chalkopyrit a pyrhotin mají stechiometrické složení bez příměsí. $V$ arzenopyritu byl zjištěn atomový poměr As/S mezi 0.98 a 1.00 a mírně zvýšené obsahy Co (max. 1.26 hm. \%) a Ni (max. 0.29 hm. \%; tab. 6). Sfalerit je z pohledu chemického složení dvojí (tab. 6): kvantitativně převažují sfalerity s vysokými obsahy železa $(8.4-10.9 \mathrm{hm} . \%)$ a mědi $(0.2-2.6 \mathrm{hm} . \%)$, zatímco druhý typ, v němž je Cu pod mezí stanovitelnosti a železo dosahuje maximálně $0.3 \mathrm{hm}$. \%, byl zjištěn jen v jediném zrně. Karbonáty dolomit-ankeritové řady jsou $v$ BSE obraze oscilačně růstově zonální. Chemické složení značně kolísá $\left(\mathrm{Dol}_{40.2-79.2} \mathrm{Ank}_{20.3-49.7} \mathrm{Ktn}_{0.5-10.4}\right)$. S rostoucím obsahem ankeritové molekuly roste i obsah kutnohoritové složky. V klasifikačním diagramu Trdličky a Hoffmana (1975) padá největší část analýz do pole Fe-bohatého dolomitu a v mnohem menší míře i do polí dolomitu a Mg-bohatého ankeritu (obr. 7). Siderity jsou rovněž chemicky variabilní $\left(\mathrm{Sid}_{58.5-76.1} \mathrm{Mag}_{14.5-37.5} \mathrm{Cal}_{2.6-7.3} \mathrm{Rdc}_{1.2-5.4}\right)$ a jde o siderity až Mg-bohaté siderity ve smyslu klasifikace Trdličky a Hoffmana (1975) - viz obr. 7.

\section{Diskuse}

\section{Porovnání s publikovanými údaji}

Malec et al. (1990) pomocí EDS analyzovali dvě zlatinky, které získal Rezek (1984) ze svahových sedimentů pod ložiskem Řepová, s následujícími výsledky: zlatinka č. 1 - průměrná ryzost $893, \mathrm{Ag} 10.2-11.2$ hm. \%, $\mathrm{Hg} 0 . X$ \%; zlatinka č. 2 - průměrná ryzost $850, \mathrm{Ag} 14.5$ - 15.7 hm. \%, Hg 0.X \%. Diplomová práce Petržely (2016) uvádí výsledky laboratorního studia 16 zlatinek, vyrýžovaných během vyhledávací akce Unigea Zlaté Hory z Ospitského potoka (odběr proveden níže po proudu potoka, už v oblasti tvořené křídovými sedimenty) a z bezejmenného přitoku Hynčinského potoka, odvodňujícího severní svah 
Tabulka 6 Příklady chemického složení pyritu (Py), sfaleritu (Sp), galenitu (Ga) a arzenopyritu (Asp) z primární žilné mineralizace od Dlouhé Vsi. Obsahy v hm. \%, hodnoty apfu jsou vypočitány na základ 2 (pyrit, arzenopyrit), resp. 1 (sfalerit, galenit) aniontu na vzorcovou jednotku.

\begin{tabular}{|c|c|c|c|c|c|c|c|c|c|c|c|c|c|c|}
\hline $\begin{array}{l}\text { An. č. } \\
\text { Minerál }\end{array}$ & $\begin{array}{r}1 \\
S p\end{array}$ & $\begin{array}{r}2 \\
S p \\
\end{array}$ & $\begin{array}{r}3 \\
S p\end{array}$ & $\begin{array}{r}4 \\
S p\end{array}$ & $\begin{array}{r}5 \\
S p \\
\end{array}$ & $\begin{array}{r}6 \\
\text { Sp }\end{array}$ & $\begin{array}{r}7 \\
\mathrm{Ga}\end{array}$ & $\begin{array}{r}8 \\
\mathrm{Ga}\end{array}$ & $\begin{array}{r}9 \\
\mathrm{Ga}\end{array}$ & $\begin{array}{l}10 \\
\mathrm{Ga}\end{array}$ & $\begin{array}{l}11 \\
\text { Py }\end{array}$ & $\begin{array}{l}12 \\
\text { Py }\end{array}$ & $\begin{array}{l}13 \\
\mathrm{Py}\end{array}$ & $\begin{array}{r}14 \\
\text { Asp } \\
\end{array}$ \\
\hline $\mathrm{Pb}$ & 0 & 0 & 0 & 0.16 & 0 & 0 & 84.84 & 84.98 & 85.45 & 85.03 & 0.14 & 0.10 & 0.18 & 0 \\
\hline $\mathrm{Cu}$ & 2.28 & 0.17 & 2.61 & 0.27 & 0 & 0 & 0 & 0 & 0 & 0 & 0 & 0 & 0 & 0 \\
\hline $\mathrm{Ag}$ & 0 & 0 & 0 & 0 & 0 & 0 & 0.29 & 0.36 & 0.30 & 0.37 & & & & \\
\hline $\mathrm{Au}$ & 0 & 0 & 0 & 0 & 0 & 0 & 0 & 0 & 0 & 0 & 0.06 & 0.06 & 0.07 & 0 \\
\hline $\mathrm{Mn}$ & 0.09 & 0.11 & 0.06 & 0.13 & 0 & 0 & 0 & 0 & 0 & 0 & 0 & 0 & 0 & 0 \\
\hline $\mathrm{Fe}$ & 9.14 & 10.65 & 8.36 & 10.93 & 0.07 & 0.29 & 0 & 0 & 0 & 0 & 45.98 & 44.62 & 46.53 & 32.40 \\
\hline Co & 0 & 0.04 & 0 & 0.03 & 0 & 0 & 0 & 0 & 0 & 0 & 0.04 & 0.71 & 0 & 1.26 \\
\hline $\mathrm{Ni}$ & 0 & 0 & 0 & 0 & 0 & 0 & 0 & 0 & 0 & 0 & 0.42 & 1.09 & 0 & 0.29 \\
\hline $\mathrm{Zn}$ & 55.29 & 55.93 & 56.07 & 55.36 & 67.57 & 67.50 & 0 & 0 & 0 & 0 & & & & \\
\hline $\mathrm{Cd}$ & 0.30 & 0.32 & 0.31 & 0.39 & 0.41 & 0.38 & 0.07 & 0.06 & 0.06 & 0 & & & & \\
\hline $\mathrm{Bi}$ & 0 & 0 & 0 & 0 & 0 & 0 & 0.71 & 0.94 & 1.07 & 1.00 & & & & \\
\hline In & 0.05 & 0.05 & 0.05 & 0.06 & 0 & 0.07 & 0.04 & 0.05 & 0.08 & 0.06 & & & & \\
\hline $\mathrm{Tl}$ & 0 & 0 & 0 & 0 & 0 & 0 & 0.21 & 0 & 0.13 & 0.17 & & & & \\
\hline As & 0 & 0 & 0 & 0 & 0 & 0 & 0 & 0 & 0 & 0 & 0 & 0 & 0 & 46.03 \\
\hline$S$ & 33.85 & 33.88 & 33.93 & 33.82 & 33.35 & 33.30 & 12.99 & 13.13 & 13.21 & 13.11 & 53.26 & 53.18 & 53.49 & 19.65 \\
\hline $\mathrm{Se}$ & 0 & 0 & 0 & 0 & 0 & 0 & 0.87 & 0.59 & 0.67 & 0.64 & & & & \\
\hline $\mathrm{Te}$ & 0 & 0 & 0 & 0 & 0 & 0 & 0.08 & 0.17 & 0.12 & 0.24 & & & & \\
\hline
\end{tabular}

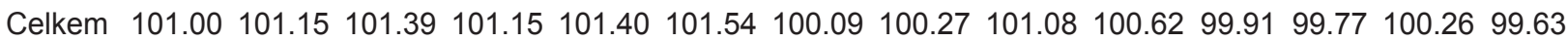

\begin{tabular}{|c|c|c|c|c|c|c|c|c|c|c|c|c|c|c|}
\hline $\mathrm{Pb}$ & 0 & 0 & 0 & 0.001 & 0 & 0 & 0.982 & 0.980 & 0.978 & 0.980 & 0.001 & 0.001 & 0.001 & $V$ \\
\hline $\mathrm{Cu}$ & 0.034 & 0.003 & 0.039 & 0.004 & 0 & 0 & 0 & 0 & 0 & 0 & 0 & 0 & 0 & 0 \\
\hline $\mathrm{lg}$ & 0 & 0 & 0 & 0 & 0 & 0 & 0.006 & 0.008 & 0.007 & 0.008 & & & & \\
\hline $\mathrm{Mn}$ & 0.002 & 0.002 & 0.001 & 0.002 & 0 & 0 & 0 & 0 & 0 & 0 & 0 & 0 & 0 & 0 \\
\hline e & 155 & 0.180 & 0.141 & 0.186 & .001 & 0.005 & 0 & 0 & 0 & 0 & 0.991 & 0.963 & 0.999 & 0.945 \\
\hline Co & 0 & 0.001 & 0 & 0.000 & 0 & 0 & 0 & 0 & 0 & 0 & 0.001 & 0.015 & 0 & 0.035 \\
\hline $\mathrm{Ni}$ & 0 & 0 & 0 & 0 & 0 & 0 & 0 & 0 & 0 & 0 & 0.009 & 0.022 & 0 & 0.008 \\
\hline n & 801 & 0.810 & 0.810 & 0.803 & .994 & 0.994 & 0 & 0 & 0 & 0 & & & & \\
\hline $\mathrm{id}$ & 0.003 & 0.003 & 0.003 & 0.003 & 0.004 & 0.003 & 0.001 & 0.001 & 0.001 & 0 & & & & \\
\hline $3 i$ & 0 & 0 & 0 & 0 & 0 & 0 & 0.008 & 0.011 & 0.012 & 0.011 & & & & \\
\hline$n$ & 0.000 & 0.000 & 0.000 & 0.000 & 0 & .001 & 0.001 & 0.001 & 0.002 & 0.001 & & & & \\
\hline Гl & 0 & 0 & 0 & 0 & 0 & 0 & 0.002 & 0 & 0.002 & 0.002 & & & & \\
\hline Cats & 0.994 & 0.998 & 0.995 & 0.999 & 0.998 & 1.003 & 1.002 & 1.001 & 1.002 & 1.002 & 1.002 & 1.001 & 1.000 & 0.989 \\
\hline As & 0 & 0 & 0 & 0 & 0 & 0 & 0 & 0 & 0 & 0 & 0 & 0 & 0 & 1.001 \\
\hline & 1.000 & 1.000 & 1.000 & 1.000 & 1.000 & 1.000 & 0.972 & 0.979 & 0.978 & 0.976 & 2.000 & 2.000 & 2.000 & 0.999 \\
\hline Se & 0 & 0 & 0 & 0 & 0 & 0 & 0.026 & 0.018 & 0.020 & 0.019 & & & & \\
\hline Te & 0 & 0 & 0 & 0 & 0 & 0 & 0.002 & 0.003 & 0.002 & 0.004 & & & & \\
\hline Ansum & 1.000 & 1.000 & 1.000 & 1.000 & 1.000 & 1.000 & 1.000 & 1.000 & 1.000 & 1.000 & 2.000 & 2.000 & 2.000 & 2.000 \\
\hline
\end{tabular}

Obr. 7 Variace $v$ chemickém složení karbonátů dolomitové skupiny (a) a sideritu (b) z žilné mineralizace z Dlouhé Vsi v klasifikačních diagramech Trdličky a Hoffmana (1976). Srovnávací data pro rudní ložisko Řepová byla převzata z Dolníčka et al. (2019).

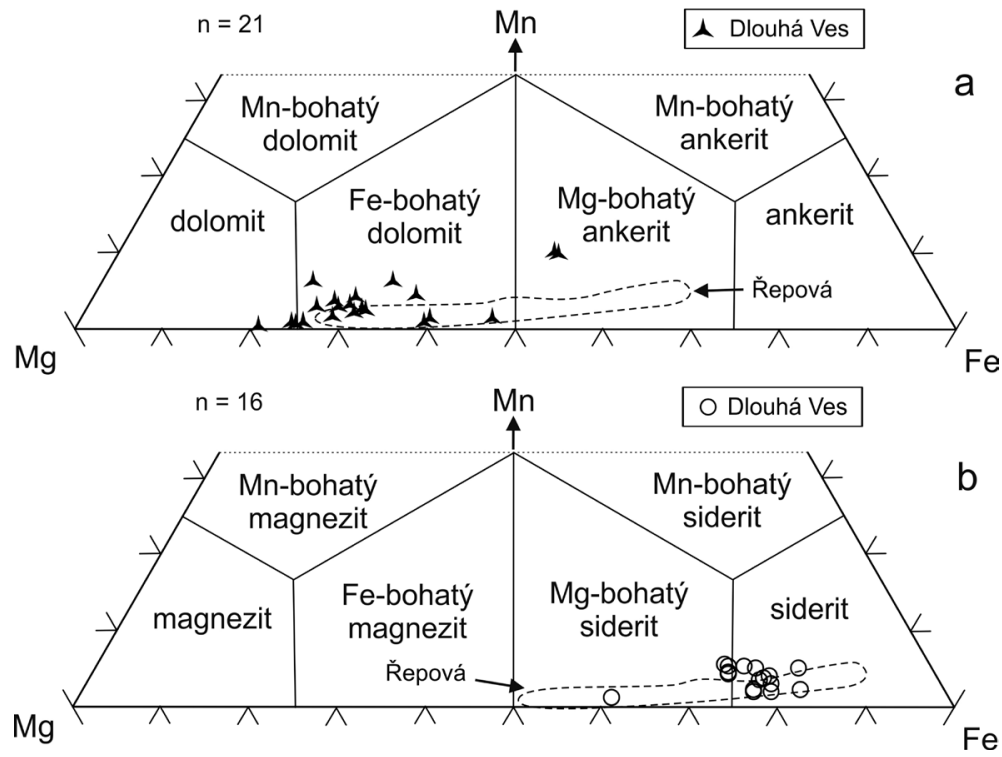


Kančího vrchu (obr. 2). Pokud jde o morfologii, vnitřní stavbu a chemické složení, autorem studované vzorky vykazují obdobné rysy jako námi studované zlatinky: převaha transportem relativně málo opracovaných typů, př́tomnost ryzejšího lemu u necelé poloviny zlatinek, široká variabilita v chemismu zlata (Ospitský potok: 59.8 - 99.1 at. \% Au; př́tok Hynčinského potoka: 51.1 - 99.5 at. \% Au), typicky nepatrná variabilita v chemismu hlavní hmoty zlatinek. Příměs rtuti byla zjištěna téměř bez výjimky jen u Hynčiny, její výskyt je nesystematický, obsahy jsou většinou jen málo zvýšené (max. 2.3 at. \%), naměřené jen v cca $20 \%$ získaných analýz. Z doprovodných fází, srůstajících se zlatem, autor zmiňuje chalkopyrit, křemen a jílový minerál z Hynčiny a dále křemen a florencit z Ospitského potoka (Petržela 2016). Přesto, že je v práci prezentováno asi 50 analýz zlata a také řada analýz doprovodných oxidických a silikátových fází ze šlichů, autor se nijak nevyjádřil k možné provenienci zlata. Jediný výskyt primárního zlata ze studované oblasti popsali Dolníček et al. (2019) z žilného polymetalického rudního ložiska u Řepové. Autoři analyzovali tři zlatinky, které byly nezonální a obsahovaly 50.1 - 65.9 at. \% Au. Jedna z nich měla i zvýšené obsahy Hg (1.3 - 2.4 at. \%). Chemické složení zlata studovaného ve všech výše uvedených pracích je rovněž znázorněno na obrázku 5 .

Chemické složení sulfidů a karbonátů z nově nalezené primární žilné mineralizace $v$ Ospitském potoce $u$ Dlouhé Vsi Ize zčásti přirovnat $\mathrm{k}$ výše zmíněnému ložisku Řepová. Pyrity z řepovského ložiska mají rovněž místy zvýšené obsahy Au (max. 0.20 hm. \%), Pb (až 0.41 hm. \%), Ni (max. 0.47 hm. \%) a Co (až 0.41 hm. \%) (Dolníček et al. 2019). Sfalerity z Řepové se vyznačují nízkým obsahem Fe (0.1 - $1.2 \mathrm{hm}$. \%), ale zvýšeným obsahem Hg (0.3 - 2.4 hm. \%; Dolníček et al. 2019), která však v nízkoželeznatém sfaleritu z Dlouhé Vsi chybí. Také chemismus karbonátů z Dlouhé Vsi je blízký rudnímu ložisku Řepová s tím, že u karbonátů dolomitové řady z Dlouhé Vsi je patrné určité obohacení hořčíkem na úkor železa (obr. 7). Naproti tomu chemismus galenitu z Dlouhé Vsi Ize v porovnání s Řepovou hodnotit jako výrazně odlišný (na Řepové zcela chybí Se a Bi, naopak je zde typickým prvkem $\mathrm{Sb}$ ), stejně jako chemismus vysokoželeznatého sfaleritu, na Řepové nezjištěného (srov. Dolníček et al. 2019). Vzhledem k prítomnosti chemicky rozdílných sfaleritů je pravděpodobné, že na Dlouhé Vsi může jít o dva odlišné typy hydrotermální mineralizace, přítomné na jedné žilné struktuře.

\section{Možný pưvod aluviálního zlata}

Námi provedené práce prokázaly prostorově omezený výskyt zlatinek se zvýšeným obsahem rtuti. Jejich výskyt byl ve sledovaném území zaznamenán pouze na dolním toku Řepovského potoka na lokalitách č. 1, 2+3 a 8 (tab. 1, obr. 2). Všechny tyto lokality jsou situovány již na horninách mírovského „kulmu“. Lokality č. 1 a 2+3 jsou situovány pod rudním ložiskem Řepová, kde byl výskyt primárního zlata se zvýšeným obsahem Hg (a také zlata bez obsahu rtuti) doložen Dolníčkem et al. (2019). Na ložisku byly dále citovanými autory akcesoricky zjištěny i další Hg-minerály, včetně cinabaritu a amalgámů stř́bra. Lokalita č. 8 je situována dále $\mathrm{k}$ SV, tj. proti proudu potoka. Uvážíme-li však skutečnost, že rudní žíly řepovského ložiska mají směr SV - JZ (Skácel 1961; Rezek 1984), tedy paralelní se směrem údolí potoka, můžeme vzhledem $\mathrm{k}$ příznivé geomorfologické situaci (sklon svahu směrem $k$ potoku) uvažovat o zdroji těchto zlatinek v hypotetickém severovýchodním směrném pokračování řepovských rudních žil (obr. 2). Všechny aluviální rtutí bohaté zlatinky a případně i cinabarit tedy mohou pocházet z uvedeného rudního ložiska. V prípadě cinabaritu však výše nastíněná interpretace zdroje neplatí bezezbytku, nebot' tento minerál byl vzácně nalezen také ještě výše proti proudu na lokalitě č. 15 . Vysvětlení původu tohoto nálezu může být dvojí: (i) výše proti proudu potoka se nachází (již v horninách zábřežského krystalinika) další výskyt cinabaritového zrudnění (avšak bez výskytu Hg -bohatého zlata) nebo (ii) může jít o bodovou kontaminaci v důsledku lidské činnosti (lokalita se nachází v centru obce Řepová).

Interpretace zdroje aluviálních zlatinek bez obsahu Hg je v zájmové oblasti přes velké množství nově nashromážděných údajů obtížným úkolem. Provedené terénní práce jasně ukázaly, že se aluviální zlato bez obsahu $\mathrm{Hg}$ vyskytuje prakticky $v$ celé zkoumané oblasti. Vzhledem k vzájemné prostorové odlehlosti pramenných oblastí všech studovaných vodních toků a $s$ přihlédnutím ke značné geomorfologické členitosti terénu (obr. 1,2) Ize vyloučit možnost, že by toto zlato mohlo pocházet $z$ jediného „bodového“ zdroje typu rudní žily či rudní zóny. I s ohledem na naše neúspěšné pátrání $v$ horninových vzorcích a nalezených větších kusech křemenné žiloviny tedy spíše predpokládáme vazbu zlata na drobné, z pohledu obsahu zlata nekontrastní (málo kovnaté) a $v$ terénu nenápadné zdroje. Vezmeme-li v potaz všechna zjištěná fakta, Ize uvažovat o dvou potenciálních zdrojích v zájmové oblasti.

Prvním možným zdrojem by mohly být drobné výskyty žilného polymetalického (?) zrudnění s akcesorickým výskytem zlata. Žilné postmetamorfní zrudnění typu Řepová (Dolníček et al. 2019) či Dlouhá Ves (tato práce) akcesoricky v zájmové oblasti obsahuje zlato, které svými charakteristikami rámcově odpovídá zdejšímu aluviálnímu zlatu. U těchto primárních zlatinek Ize rovněž konstatovat značný rozsah v ryzosti (užší rozsah zjištěný pro primární zlata by mohl být zapř́činěn velmi malým počtem - celkem 4 ks - dosud nalezených a analyzovaných zlatinek) a také absenci výraznější kompoziční zonálnosti. Tento typ mineralizace, pokud by byl $v$ daném terénu hojněji př́tomen (srov. Morávek 1995), ale vytvářel jen drobné, málo mocné žilky, zcela naplňuje představu „neviditelného“, respektive jen velmi obtížně lokalizovatelného zdroje zlata, vzhledem ke skutečnosti, že jak Ca-Mg-Fe karbonáty, tak obecné sulfidy snadno podléhají zvětrávání.

Druhým možným potenciálním zdrojem zlata by mohly být metamorfované horniny zábřežského krystalinika, jmenovitě ty, které jsou v dané oblasti hojně rozšířené a jejichž protolit mohl původně obsahovat zlato. $\mathrm{K}$ úvaze tímto směrem nás vede jednak $v$ aluviálních zlatinkách opakovaně zjišt'ovaná asociace zlata s fylosilikáty a živci a jednak také uniformně zvýšená koncentrace Au v pyritech různých genetických typů, nasvědčující zvýšenému fónu Au v zájmové oblasti. Za prvé Ize uvažovat o př́tomnosti klastického zlata $v$ původních sedimentech, jejichž metamorfózou vznikly metaprachovce. Pokud by toto klastické zlato bylo $v$ původním sedimentu rozptýleno relativně rovnoměrně, je zřejmé, že i v takové situaci Ize získat plošně rozsáhlou šlichovou anomálii zlata, k níž Ize jen velmi obtížně dohledat zdroj. Za druhé, zlato by mohlo být vázáno i na polohy kyselejších typů metavulkanitů, čemuž by nasvědčovala přítomnost supersolvního Na-K živce $v$ asociaci se zlatem. Hydrotermální aktivita spojená s extruzí ryolitového/dacitového 
magmatu $v$ některých případech vede i ke vzniku ložiskově významných akumulací zlata (srov. Hollister, Jennings 1993; Haller 1997). Pozorovaná značná variabilita ryzosti zlatinek $v$ kombinaci $s$ absencí jejich zonálnosti v případě uvažovaných "horninových zdrojů“ není překážkou, uvážíme-li, že ryzost zlata závisí na řadě faktorů, včetně Au/Ag poměru v daném systému, dále na teplotě, fugacitě síry, $\mathrm{pH}$, Eh a koncentraci chloridů v koexistujících fluidech (např. Shikazono, Shimizu 1987; Morrison et al. 1991; Gammons, Williams-Jones 1995). Možná primární variabilita $v$ chemickém složení zlata $v$ protolitu metamorfitů mohla být tedy dále výrazně modifikována během naložené metamorfózy vzhledem k nehomogenitě lokálních hodnot $\mathrm{pH}$, Eh a fugacity síry $\mathrm{v}$ jednotlivých „vrstvách“ původní vulkanosedimentární sekvence, lišících se přítomností, respektive nepřítomností pyritu, karbonátů, oxidů železa či organické hmoty. Zároveň při teplotách nad $300-400{ }^{\circ} \mathrm{C}$ dochází vlivem difuze v pevném stavu $\mathrm{k}$ homogenizaci chemického složení zlatinek (Kucera, Million 1970; Gammons, Williams-Jones 1995), takže původní eventuálně přítomná chemická zonálnost jednotlivých zlatinek by byla regionálně-metamorfními procesy probíhajícími v zájmové oblasti zcela odstraněna.

\section{Původ antropogenních slitin}

Část kovových slitin, vyrýžovaných z náplavů Řepovského potoka u Krchleb a Řepové (lokality č. 15 a 26), představuje produkty moderní metalurgie (manganová ocel, kuličky ferosilicia). Zajímavé jsou však slitiny Cu-Zn -Sn, které vykazují poměrně značně variabilní a exotické chemické složení [někdy navíc s uzavřenými inkluzemi olova (!)], k nimž těžko hledat moderní analogie. Vzhledem k prítomnosti minoritních obsahů $\mathrm{Sb}, \mathrm{Ni}$ a In (tab. 5) nelze vyloučit možnost, že tyto slitiny obsahují kovy získané hutněním rud z Pb-Zn-Ag ložiska Řepová, které je mj. charakteristické i akcesorickým výskytem četných minerálů $\mathrm{Sb}$ a Ni a prítomností příměsi In ve sfaleritu (Dolníček et al. 2019). O existenci huti u Řepové či Krchleb, která měla zpracovávat rudu vytěženou na ložisku v Řepové a také železnou rudu vytěženou $v$ okolních dolech, je zmínka v urbári mírovského panství z roku 1526 (Štěpán 2004). Přesná lokalizace hutě však není známa. Dle výsledků šlichových zkoušek se jako nejpravděpodobnější varianta jeví umístění huti v intravilánu Krchleb. Př́itomnost kovového olova a hlavně klejtu jsou dalšími indikátory hutního provozu zpracovávajícího olověné a/nebo stř́ibrné rudy. Přítomnost cínu ve vyrýžovaných slitinách, který v řepovských rudninách není přítomen, Ize vysvětlit jedině použitím rud či kovů i z dalších lokalit.

\section{Závĕr}

Detailní šlichová prospekce na Řepovském potoce, Mírovečku a Ospitském potoce v severní části Zábřežské vrchoviny ukázala, že se aluviální zlato vyskytuje v celé této oblasti. Zlatinky mají velikost mezi 0.2 a $3 \mathrm{~mm}$ a transportem většinou relativně málo opracovanou morfologii. Ačkoliv chemické složení celé populace nalezených zlatinek široce kolísá mezi zlatnatým stříbrem a čistým zlatem (28.1 - 99.8 at. \% Au), jednotlivé zlatinky jsou až na několik výjimek kompozičně homogenní. Jen necelá polovina zlatinek má na okraji ryzejší lem, vzniklý vyloužením stříbra $v$ supergenních podmínkách. Na dolním toku Řepovského potoka byly lokálně zjištěny zlatinky obsahující i rtut' (0.1 - 5.1 at. \%), které patrně pocházejí ze sousedního žilného Ag-Zn-Pb ložiska Řepová. Zdroj zlatinek bez obsahu $\mathrm{Hg}$ se nepodařilo jednoznačně prokázat, v úvahu připadají bud' drobné žilné mineralizace obdobné ložisku Řepová (výskyt tohoto typu byl nově nalezen na Ospitském potoce u Dlouhé Vsi), případně nelze vyloučit ani možnost akcesorického výskytu zlata přímo v metaprachovcích či kyselých metavulkanitech zábřežského krystalinika (vzhledem k běžně zjištěným srůstům aluviálního zlata s fylosilikáty a alkalickými živci). Částice kovových $\mathrm{Cu}-\mathrm{Zn}$-Sn slitin s príměsí $\mathrm{Ni}, \mathrm{Sb}$ a In, vyrýžované $v$ Řepovském potoce, mohou pocházet $z$ hutnického zpracování Ag-Pb-Zn rud z ložiska Řepová, které obsahují tytéž minoritní prvky.

\section{Poděkování}

Předložená práce vznikla za finanční podpory Ministerstva kultury v rámci institucionálního financování dlouhodobého koncepčního rozvoje výzkumné organizace Národní muzeum (DKRVO 2019-2023/1.II.b, 00023272). Oběma recenzentům (S. Houzar a J. Malec) autoři děkuji za podnětné připomínky, které přispěly ke zvýšení kvality rukopisu.

\section{Literatura}

Abraham M, Hranáč P, Hưlka L, Luna J, Švestka J, VeleBA B, ŽAČEK M (1995) Regionální šlichová prospekce České republiky, dílči úkol IV - Vymezené prostory a dílčí úkol V - Orlické hory, závěrečná zpráva. Mapy distribuce minerálů a prvků 1:200 000, šlichové mapy 1:50 000. MS, Geoindustria Jihlava

Albrechtová E, Zielinová M (1984) Šlichová prospekce. Závěrečná zpráva. MS, Geol. Průzkum Ostrava, Zlaté Hory

Dolní̌̌ek Z, Nepejchal M, Ulmanová J (2019): Řepová u Mohelnice - mineralogicky nejpestřejší žilný rudní výskyt v moravskoslezském kulmu. Bull Mineral Petrol 27: 109-135

Gammons CH, Williams-Jones AE (1995) Hydrothermal geochemistry of electrum: thermodynamic constraints. Econ Geol 90: 420-432

HALLER MJ (1997) The rhyolite field related gold deposits from Patagonia. In: Papunen H (ed) Mineral Deposits: Research and Exploration Where Do They Meet? 201-203 A.A. Balkema Rotterdam

Hollister VF, JenNings DS (1993) Relationship between low-grade gold disseminations and high-grade veins in the Quartz Mountain district, Oregon. Nonrenew Res 2: 284-291

Koverdynský B, KonzÁlová M (1986) Problematika stratigrafického zařazení zábřežské skupiny. Věst Ústř Úst geol 61: 159-167

Krupp RE, Weiser T (1992) On the stability of gold-silver alloys in the weathering environment. Miner Deposita 27: $268-275$

KuCERA J, Million B (1970) Self-diffusion in substitutional solid solutions with Fcc lattice. Metallurg Transact 1: 2603-2606

MALEC J (2002) Morfologie a složení zlata z aluviálních rozsypů v České republice. Bull mineral-petrolog Odd Nár Muz (Praha) 10: 156-166

Malec J, Kavalír J, Jansa J (1990) Zlato a doprovodné minerály z oblasti Jeseníků. MS, Ústav nerostných surovin Kutná Hora

MoRÁvek P (2015) Mapy výskytů zlata v České republice. Čes geol služba, Praha 
Morávek P, Aichler J, DošKáR̆ Z, Duda J, Ďurišová J, Hauk J, Janatka J, Kalenda F, Klomínský J, KvĚtoñ P, Litochleb J, Malec J, Mrázek I, Novák F, Pouba Z, Pudilová M, PunčocháR̆ M, SKácel J, SOUKup B, StudNIČnÁ B, Sztacho P, Š́ponar P, TÁsler R mL, Váña T, VanĚČek M, VeSELÝ J (1992) Zlato v Českém masívu. Vydavatelství Čes geol úst, Praha

MORÁVEK R (1995) Zpráva o geologicko-petrografických výzkumech $v$ jižní části zábřežského krystalinika. Geol výzk Mor Slez 2: 100-102

Morrison GW, Rose WJ, JAIRETH S (1991) Geological and geochemical controls on the silver content (fineness) of gold in gold-silver deposits. Ore Geol Rev 6: 333364

OtAVA J, Maštera L, HanžL P (1994) Nové poznatky o geologii jižní a střední části malonínské hrásti. Geol Výzk Mor Slez v r 1993, 1: 47-51

Petržela M (2016) Asociace Au a doprovodných těžkých minerálů ze šlichů v oblasti Hynčiny. MS, diplomová práce, PřF MU Brno

Pouchou J, PICHOIR F (1985) „PAP“ ( $\varphi \rho z)$ procedure for improved quantitative microanalysis. In: ARMSTRONG JT (ed): Microbeam Analysis: 104-106. San Francisco Press. San Francisco
REZEK K (1984): Mineralogicko-geochemická charakteristika zrudnění u Řepové. Acta Mus Moraviae, Sci Geol 69: $37-43$

Shikazono N, Shimizu M (1987) The Ag/Au ratio of native gold and electrum and the geochemical environment of gold vein deposits in Japan. Miner Deposita 22: 309-314

SKÁCEL J (1961) Ke genesi rudních ložisek u Květína mezi Mohelnicí a Zábřehem na Moravě. Čas Mor Muz v Brně, Vědy přír 46: 27-32

ŠteLCL J, BROTHÁNEK J (1961) Zpráva o petrografickém výzkumu mírovských slepenců. Čas Slez Muz Opava (A) 10:63-67

ŠTĚPÁN J (2004) Získávání drahých kovů na statcích olomouckého biskupství za Stanislava Pavlovského z Pavlovic (1579-1598). Acta Montan Slov 9, 2: 141144

TRDLIČKA Z, HOFFMAN V (1975) Untersuchungen der chemischen Zusammensetzung der Gangkarbonate von Kutná Hora (ČSSR). Freiberg Forschungshefte 6: 2981

ZAPLETAL J (1994) Mírovské konglomeráty - nejstarší člen flyšových variscid na Moravě. Geol Průzk 34: 180-183 